\title{
A Systematic Review on Antitumor Agents with 1, 3, 5-triazines
}

\author{
Beibei Liu, Tiemin Sun*, Zhixu Zhou and Lei Du \\ Department of Key Laboratory of Structure-Based Drug Design and Discovery, Shenyang Pharmaceutical University, Shenyang, China
}

\begin{abstract}
1, 3, 5-triazine derivatives have received considerable attention owing to their broad biological activities, which have made it an indispensable anchor for development of new therapeutic agents. Owing to fast development of new drugs possessing 1, 3,5-triazine nucleus, many research reports are generated in a short span of time. Although only a few compounds have at present progressed into human clinical trials, the prospect of finding safe agents useful in therapy, particularly in the cancer setting, is still positive. To our knowledge, few systematic reviews on triazines have been conducted to date. In this review, we have highlighted various inhibitors with 1, 3, 5-triazine core which targeting different kinases with an aim to help medicinal chemists for developing structure-activity relationship on 1, 3, 5-triazine derived compounds for antitumor activity.
\end{abstract}

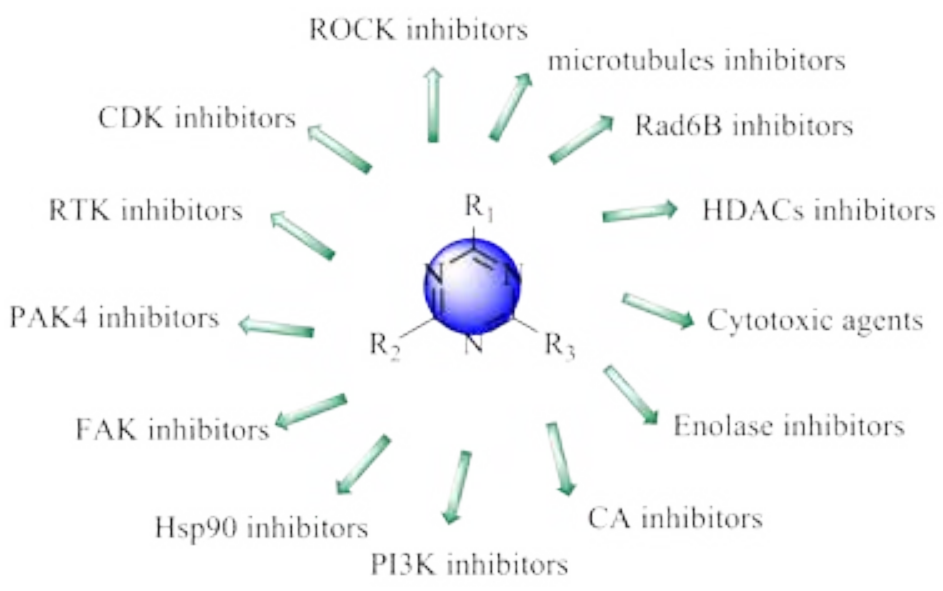

Keywords: 1, 3, 5-triazines; Kinases; Inhibitors; Antitumor; Target; Agents

\begin{abstract}
Abbreviations: PI3Ks: Phosphoinositide 3-kinases; PIKKs: Mammalian Target of Rapamycin; PKB: Protein Kinase B; PDK1: Phosphoinositide Dependent Kinase 1; mTOR: Mammalian Target of Rapamycin; DNA-PK: DNA dependent protein kinase; MTD: Maximum tolerated dose; $\mathrm{EC}_{50}: 50 \%$ Effective dose; $\mathrm{IC}_{50}:$ Half maximal inhibitory concentration; HGF: Hepatocyte Growth Factor; Hsp90: Heat Shock Protein 90; ATP: Association Tennis Professional; CA: Carbonic Anhydrases; HIF-1: Hypoxia-Inducible Factor; RTK: Receptor Tyrosine Kinases; VEGFR: Vascular Endothelial Growth Factor Receptor; FAK: Focal Adhesion Kinase; ECM: Extracellular Matrix; CDKs: Cyclin-Dependent Kinases; ROCKs: Rho-Associated Protein Kinases; HDACs: Inhibition of Histone Deacetylases
\end{abstract}

\section{Introduction}

The 1,3,5-triazine skeleton is one of the most interesting chemical core structures subjected to extensive study in recent years and its derivatives has a wide variety of applications so far. In recent years, versatile bioactivities of 1,3,5-triazine derivatives have been extensively reported [1]. Pharmacologically effective compounds were also used for the treatment cardiovascular, neuropsychiatric disorders, diabetes, diuretics [2-4].

The area of drug research has experienced significant advances with the introduction of 1,3,5-triazine skeleton, particularly noteworthy happens to antitumor activity. Additionally, many 1, 3, 5-triazine derivatives have proved to hold great promise for further development as new hits of antitumor agents [5-9]. The attractive reasons of 1, 3, 5-triazine scaffold were as follows: (1) 1, 3, 5-triazine has been utilized as a kinase inhibitor scaffold which is monocyclic and symmetrical [10]. (2)The polarity of the whole molecule can be inherently imparted by three nitrogens presented at the 1,3,5-triazine core, and the designed compounds' clogP values can be lower. (3) Amide functionality with water stabilizing groups improved potency both in enzyme and in cell proliferation assays [11]. It has been extensively reported that the presence of sulfonamide, morpholine, or pyrimidyl moieties at 2, 4 or 6-positions of the 1,3,5-triazine core enhanced antitumor activity. These molecules may demonstrate remarkable pharmacokinetics and oral bioavailability with additional modifications.

Due to the fast development of new drugs for 1, 3, 5-triazine skeleton, a large amount of research articles are arose in fast speed [12]. But unfortunately, there is no description in the article to reveal the characteristic features of their relationship between 1, 3, 5-triazine derivatives and the cancer targets. The present review would be aimed at filling this gap and showing the prospects of further investigations of

${ }^{*}$ Corresponding author: Tiemin Sun, Department of Key Laboratory of StructureBased Drug Design and Discovery, Shenyang Pharmaceutical University, Shenyang 110016, China, Tel: 86-13386838360; E-mail: suntiemin@163.com

Received March 16, 2015; Accepted March 28, 2015; Published March 30, 2015

Citation: Liu B, Sun T, Zhou Z, Du L (2015) A Systematic Review on Antitumor Agents with 1, 3, 5-triazines. Med chem 5: 131-148. doi:10.4172/21610444.1000255

Copyright: @ 2015 Liu B, et al. This is an open-access article distributed under the terms of the Creative Commons Attribution License, which permits unrestricted use, distribution, and reproduction in any medium, provided the original author and source are credited. 
$1,3,5$-triazine derivatives in a search for further antitumor agents on selected cancer targets.

\section{1, 3, 5-triazine Derivatives Targeting Kinases}

Kinase selectivity plays a major role in the design strategy of lead series and in the ultimate success of kinase drug discovery programs. Identifying and understanding small molecule kinase inhibitor selectivity is still a major challenge. Selectivity is often achieved by targeting specific inactive states of the kinase. These states did not evolve to recognize ATP and are often sufficiently different across the kinome. Selectivity can also be increased by targeting specific subpockets such as the hydrophobic pocket behind the "gatekeeper" residue or solvent exposed residues outside the ATP binding site [13]. A series of 1, 3, 5 -triazine derivatives were developed as orally active and selective antitumor agents starting from promiscuous kinase hits. Based on molecular modeling and docking analysis, various substituents at the 2, 4, 6-positions of the 1, 3, 5-triazine core were introduced to fit into a small binding pocket which does not exist in regular protein kinases near the hinge region to improve kinase selectivity. Antitumor agents with 1,3,5-triazines have been shown to localize selectively in tumors by binding to specific kinase binding site, such as PI3K, EGFR, ROCK, etc. [14].

\section{1, 3, 5-triazine derivatives targeting phosphoinositide 3-kinases}

In the 1980s, L.C. Cantley first discovered phosphoinositide 3-kinases (PI3Ks) which phosphorylate the 3-hydroxy group of phosphoinositides $[15,16]$. Three classes of highly conserved proteins of the PI3K family have distinct substrate preferences and regulation mechanisms $[17,18]$. Class I PI3Ks are heterodimers making up of a catalytic subunit (p110a, p110 , p110 $\gamma$ and $\mathrm{p} 110 \delta$ ) and a regulatory subunit which are most well characterized [19]. Phosphorylation capability of class II and III PI3Ks is similar to class I PI3Ks but not well understood $[20,21]$. Furthermore, the mammalian target of rapamycin (mTOR) and DNA dependent protein kinase (DNA-PK) are PI3Krelated protein kinases (PIKKs) and they are always regarded as class IV PI3Ks owing to their similar catalytic cores to PI3Ks [14].

Protein kinase B (PKB/Akt), mTOR and phosphoinositide dependent kinase 1 (PDK1) are the phosphorylated downstream effectors of PI3Ks, triggering a signaling cascade that is closely connected with various cellular activities [22-24]. Stimulated by receptor tyrosine

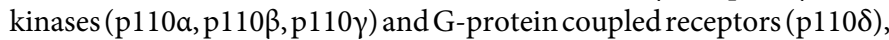
class I PI3Ks regulate most known PI3K signaling effects through the formation of phosphatidylinositol 3, 4, 5-triphosphate (PIP3), which recruits downstream effectors such as Akt, PDK1, and mTOR $[25,26]$. During the PI3K-mediated activation process, the phosphatase and tension homologue deleted on chromosome ten (PTEN) functions as a negative regulator by converting PIP3 to PIP2 (Figure 1) [27-29]. The $\mathrm{PI} 3 \mathrm{~K}$ is a well understood target for anticancer therapy confirmed with accumulating evidence that PI3K pathway is a most widely activated signaling pathway in cancer. This pathway plays a major role not only in tumor development but also in the tumor's potential response to cancer treatment. Amplification or over-expression by mutation of the catalytic subunit $\mathrm{p} 110 \mathrm{a}$ occurs in various types of tumors. Mutations in PIK3CA, the gene that encodes p110a, have been found in more than $30 \%$ of solid tumors, such as ovarian, pancreas, breast and stomach malignant tumors [14].

Different kinds of PI3K inhibitors including compounds with different selectivities against the four isoforms of class I PI3Ks knock down the PI3Ks and other downstream enzymes. Therefore, small molecules targeting PI3K are currently in progress as one of the most promising new approaches to cancer therapy and several inhibitors is in clinical trial [30-32].

Pan inhibitors of class I PI3K: ZSTK474 (Figure 2) is a pan class I PI3K inhibitor in phase I clinical trial potently competing with ATP, and inhibit against $\mathrm{p} 110 \alpha, \mathrm{p} 110 \beta, \mathrm{p} 110 \gamma$ and $\mathrm{p} 110 \delta$ with $\mathrm{IC}_{50}$ of 16,44 , 5 and $49 \mathrm{nM}$ respectively $[33,34]$. ZSTK474 showed potent antitumor activity and reduced Akt phosphorylation without toxic effects in human cancer xenografts after oral administration to mice [34]. The co-crystal structure of the PI3K $\delta$-ZSTK474 complex demonstrates the binding mode: the oxygens of one morpholine other than nitrogen of benzimidazole as the hydrogen bond acceptor equivalent to the adenine N1 of ATP and interacts with the backbone of Val828 (Figure 3) [35].

Bearing appropriate groups at the 4- and 6-positions of the benzimidazole ring of ZSTK474 suggested by molecular modeling could lead to stronger binding derivatives. Compound 2 (Figure 2) was identified as a very potent analogue by Gordon et al. showed exceptional potency against two mutant p110a isotherms H1047R and E545K [36]. Based on the cell researches and pharmacokinetics data in a U87MG human glioblastoma xenograft model, compound 2 significantly reduced tumor growth at MTD (maximum tolerated dose). However, compound 2 is not well tolerated in vivo due to the poor solubility properties despite the fact that with better pharmacokinetics and hopeful anticancer activity. The 4-OMe-6-aza compound 3 (Figure 2) was displayed dramatic loss of activity against $\mathrm{p} 110 \alpha, \mathrm{p} 110 \beta$, and $\mathrm{p} 110 \delta$ compared with compound 2 which showed that the electron withdrawing effect being highly unfavorable to moral activity. Synthetic study on PI3K inhibitors with the triazine skeleton structure has proceeded recently [37].

Adrian et al. identified that compound 4 (Figure 2) selectively inhibit class I PI3Ks over mTOR, or other protein kinases, Compound 4 activated PI3K/Akt pathway and also showed a robust PD-PK relationship with potent antitumor activity in a U87MG xenograft model in vivo [38]. In 2012, Mark et al. reported the optimization of compound 4 which led to a potent pan class I PI3Ks inhibitor AMG 511 (Figure 2). AMG 511 showed potently antitumor activity targeted blocking PI3K pathway in a mouse liver pharmacokinetics model $\left(\mathrm{EC}_{50}\right.$

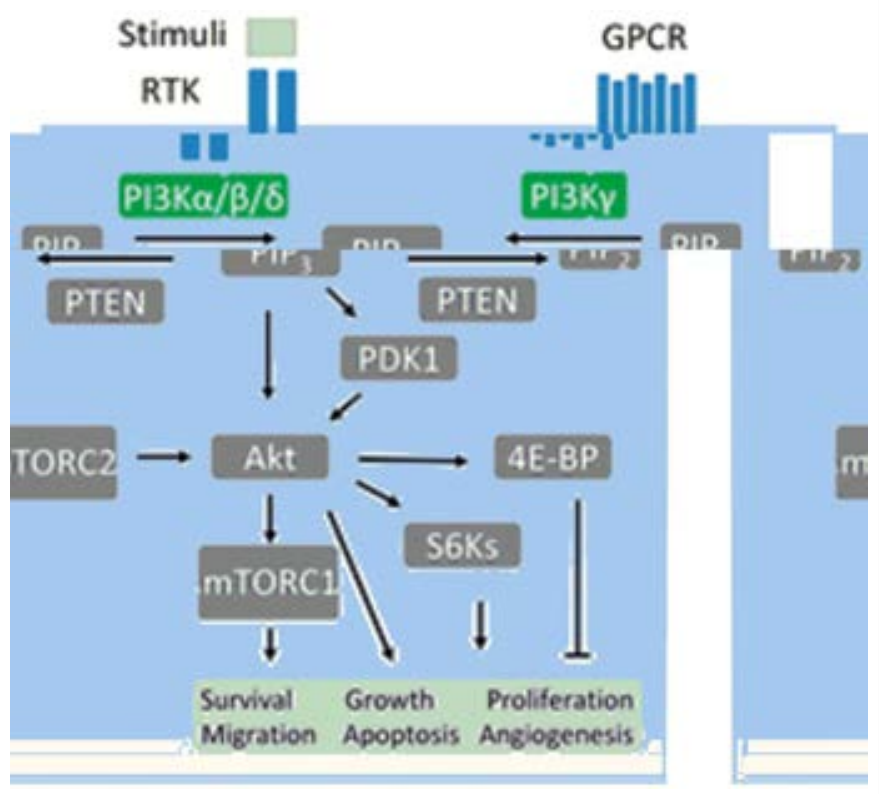

Figure 1: PI3K signaling pathway. 
<smiles>FC(F)C1Nc2ccccc2N1c1nc(N2CCOCC2)nc(N2CCOCC2)n1</smiles>

ZSTK474(1)<smiles>COc1cncc2c1nc(C(F)F)n2-c1nc(N2CCOCC2)nc(N2CCOCC2)n1</smiles><smiles>COc1cc(N)cc2c1nc(C(F)F)n2-c1nc(N2CCOCC2)nc(N2CCOCC2)n1</smiles>

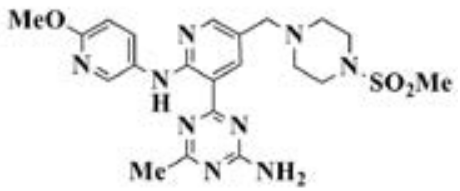<smiles>[Y14]C(c1cnc(Nc2cnc(OC)c(F)c2)c(-c2nc(N)nc(C#N)n2)c1)N1CCN(C(C)(C)C)CC1</smiles>

AMG 511(5)

Figure 2: Pan inhibitors of class I PI3K.
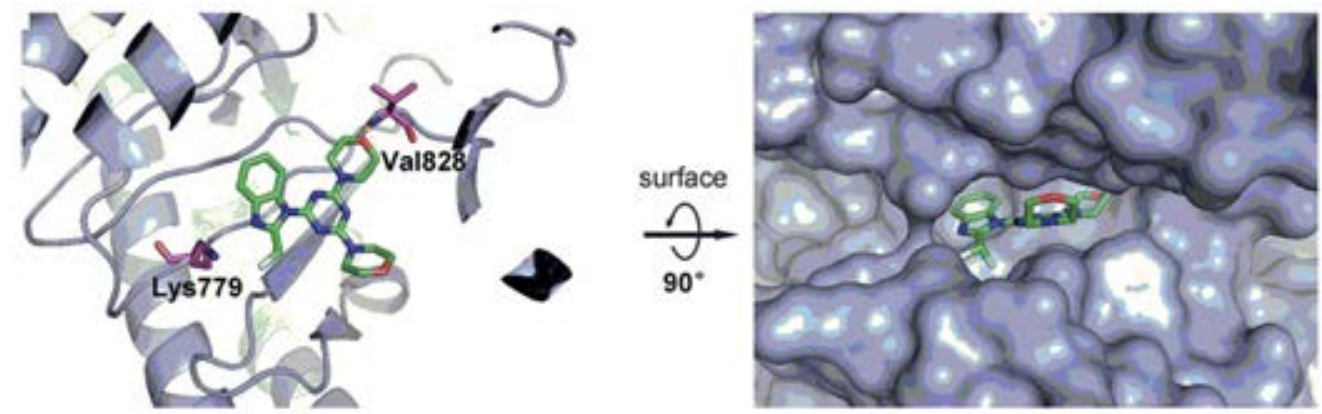

Figure 3: Co-crystal structure of PI3Kס-ZSTK474 complex. Orange dashed line indicates hydrogen bond, PDB ID: 2WXL, 1.99 A . Prepared using PyMOL.

$=228 \mathrm{ng} / \mathrm{ml}$ ) [39]. AMG 511 is a clinical candidate for cancer treatment according to its significant pharmacokinetic properties and efficacy in vivo.

Selective inhibitor of class I PI3Ks: Class I pan-PI3K inhibitors are more common in clinical trials at present in that PI3K isoforms have some similar physiological effects, while selective PI3K inhibitors likely have some therapeutic superiority owing to reduce off-target influences [40]. Recently, isoform-selective inhibitors with 1, 3, 5-triazine core are more developed in this field [41-43].

BKM120 (Figure 4) is a 2, 4-bismorpholinopyrimidyl PI3Ka inhibitor with an $\mathrm{IC}_{50}$ value of $0.03 \mu \mathrm{M}$ and it is undergoing Phase III clinical trials at present [14]. In 2012, a number of pyridine substituted triazine derivatives were discovered by Smith et al. with compound 7 (Figure 4) showing most activity and selectivity for PI3Ka over mTOR [44]. Compound 7 robustly inhibited HGF-induced Akt phosphorylation orally at both 25 and $75 \mathrm{mg} / \mathrm{kg}$ for $8 \mathrm{~h}$ and also continued to have inhibition for $24 \mathrm{~h}$ with a higher dose in the liver.

Recently, some potent and isoform-selective inhibitors of PI3K $\beta$ with aminoacyl-triazines were designated by Pinson et al. on the strength of ZSTK474. The compounds showed preferring PI3K $\beta$ selectivity with $\mathrm{L}$-amino acyl derivatives, but favored $\mathrm{PI} 3 \mathrm{~K} \delta$ with their D-congeners according to stereochemistry. The method to examine 
<smiles>Nc1cc(C(F)(F)F)c(-c2cc(N3CCOCC3)nc(N3CCOCC3)n2)cn1</smiles>

6<smiles>COc1ccc(Nc2ncc([C@H](C)N3CCN(S(C)(=O)=O)CC3)cc2-c2nc(C)nc(N)n2)cn1</smiles>

7

Figure 4: PI3Ka selective inhibitors.

the mechanism of this inhibition is using site-directed mutants [45]. The decisive factor binding to the PI3K $\beta$-selective inhibitors were identified as one Asp residue, D862, differentiating this category from other known PI3K $\beta$-selective inhibitors. The selectivity of PI3K $\beta$ was established by the effect of interaction between the primary amino substituent of inhibitors and the not conservative residues of the binding site. The inhibitors show an alternate mechanistic basis for selectivity in comparison to other recently reported selective inhibitors [45].

Notably, compound 8 (Figure 5) was 15 -fold selective for PI3K $\beta$ over PI3K $\delta$ introducing a L-alanine group, while exhibited 15 -fold selectivity for PI3K $\delta$ over PI3K $\beta$ introducing the opposite stereoisomer with a $\mathrm{D}$-alanine substituent (Figure 5). Compound 10 (Figure 5) with L-Phe was 35 -fold selective for PI3K $\beta$ over PI3K $\delta$. Compound 10 demonstrated comparable efficacy to ZSTK474 in cell growth and strongly inhibited cellular Akt phosphorylation with $\mathrm{IC}_{50}$ values $<10$ $\mathrm{nM}[45]$.

\section{1, 3, 5-triazine derivatives targeting mTOR}

The mammalian target of rapamycin (mTOR) is high molecular mass serine/threonine protein kinases belong to PIKKs. mTOR is validated as an anticancer therapy target in clinical study [46-49]. The mTOR pathway regulates growth factor signaling, recognizes cellular nutrients and energy availably, and eventually mediates cell functions depending on two distinct multi-protein complexes, mTOR complex 1(mTORC1) and mTOR complex 2 (mTORC2) [50]. mTORC1 phosphorylates the substrates $4 \mathrm{EBP} 1$ and $\mathrm{S} 6 \mathrm{~K}$ in cell translation and growth, whereas mTORC2 phosphorylates S473 to activate AKT signaling. Both of them are in charge of PI3K/AKT pathway wherein signaling ingredients usually mutate in cancer cells [50]. The most appealing treatment with cancer is targeting mTOR kinase in the past few years [51].

Compound 11 (Figure 6) showed highly potency and selectivity inhibition in human tumor xenografts models. The clinical evolution of compound 11 was prevented from its fast degradating through human microsomes $\left(\mathrm{t}_{1 / 2}<5 \mathrm{~min}\right)$ regardless of the fact that displayed significant stability in nude mouse microsomes $\left(t_{1 / 2}>30 \mathrm{~min}\right)$ [52]. Compound 12 (Figure 6) is a potent and selective mTOR inhibitor generating efficacy in vivo at low doses as never before in mouse tumor xenograft models. The remarkable potency, selectivity over PI3Ka and stability in microsomal through various species of compound 12 facilitated its further evaluation. Firstly, 12 was selective over other kinases except PI3Ka. The $\mathrm{IC}_{50}$ against PI3K- $\gamma$ was $1256 \mathrm{nM}$ (2730-fold selective). Besides, 12 was supposed to inhibit a panel of 21 kinases without $\mathrm{IC}_{50}$ 's below $50 \mu \mathrm{M}$ (>100,000-fold selectivity). The low clearance $(0.0083$
$\mathrm{mL} / \mathrm{min} / \mathrm{million}$ cells) and high half-life (>60 min) of compound 12 verified the significant stability in human hepatocytes as well as human microsome. Finally, cardiac potential and drug interactions of it were explored.

Compound 13 (Figure 6) was recorded as mTOR inhibitor selective over PI3K and inhibited downstream substrate Pakt of mTOR kinase up to $83 \%$ exhibiting dose-dependent inhibition [37]. This compound inhibited 18 cancer cell-lines' proliferation $\left(\mathrm{IC}_{50}<1 \mu \mathrm{M}\right)$ in tissue culture experiments, HGF-stimulated Akt phosphorylation in liver at $30 \mathrm{mg} / \mathrm{kg}$ and S6RP phosphorylation at $100 \mathrm{mg} / \mathrm{kg}$ in vivo tests. Compound 14 (Figure 5) was more than 100-fold selective over the other PI3K isotherms, furthermore, 14 was selected in order to research the selectivity of mTOR inhibitor on cancer cell lines that observed high clearance and poor exposure in vivo although the best potency/ selectivity combination [54].

Bearing morpholines with pyrazolopyrimidine (Figure 6) and thienopyrimidine (Figure 6) scaffolds with a para-ureidophenyl substituent result in greater selective mTOR inhibitors for PI3K than the analogs containing morpholine [55]. Compound 17 (Figure 6) demonstrated selectively restraining mTOR activity both in U87MG tumors in nude mice in vivo and in MDA361 cells in vitro.

Some molecules with a central triazine skeleton and a morpholine substituent like 18 (Figure 6) were sub-micromolar mTOR inhibitors. Compound 18 showed a five-fold selectivity towards mTOR contrast to PI3Ka, is under a lower molecular weight of 356 Dalton and higher mTOR ligand efficiency of $0.34 \mathrm{kCal} / \mathrm{mol} / \mathrm{HA}$. Anders Poulsen et al. have reported that compound 19 (Figure 6) was slightly better potent to mTOR with high LE of $0.39 \mathrm{kCal} / \mathrm{mol} / \mathrm{HA}$ [56].

The 2, 5-bridged morpholine derivative (Figure 6) displayed excellent potency against mTOR with $\mathrm{IC}_{50}$ of 250 and $300 \mathrm{nM}$ in LNCaP prostate and MDA468 breast cancer cells assays respectively. Compound 21 (Figure 6) with (R)-3-methylmorpholine led to enhancing activity against mTOR and increase corresponding activity in cellular. A thorough investigation of alternative urea derivatives was prompted as the potential of 21 [57].

BMCL-200908069-1 (Figure 6) potently inhibited mTOR with an $\mathrm{IC}_{50}$ of $0.27 \mu \mathrm{mol} / \mathrm{L}$. Compound 23 (Figure 6) was reported by HUANG Qiang et al. and it is more active than BMCL-200908069-1 against HT-29, H460 and MDA-MB-231 cancer cell-lines [58]. Zhu et al. reported that mTOR activity of compound 24 (Figure 6) (with $\mathrm{IC}_{50}$ of $0.05 \mu \mathrm{M}$ ) was exhibited with significant selectivity for the $\mathrm{H} 460$ tumor cell line and high antiproliferative activity evaluated by LANCE [59]. Compound 24 showed strong antiproliferative activity for the H460, HT-29, and MDA-MB-231 cell-lines with $\mathrm{IC}_{50}$ of $0.05,6.30$, and 6.49 
<smiles>CC(N)C(=O)N1CCN(c2nc(N3CCOCC3)nc(-n3c(C(F)F)nc4ccccc43)n2)CC1</smiles>

8<smiles>C/C=C\C=C/C(=O)N1CCN(c2nc(N3CCOCC3)nc(-n3c(C(F)F)nc4ccccc43)n2)CC1</smiles>

9<smiles>N[C@@H](Cc1ccccc1)C(=O)N1CCN(c2nc(N3CCOCC3)nc(-n3c(C(F)F)nc4ccccc43)n2)CC1</smiles>

10

Figure 5: PI3K $\beta$ selective inhibitors.

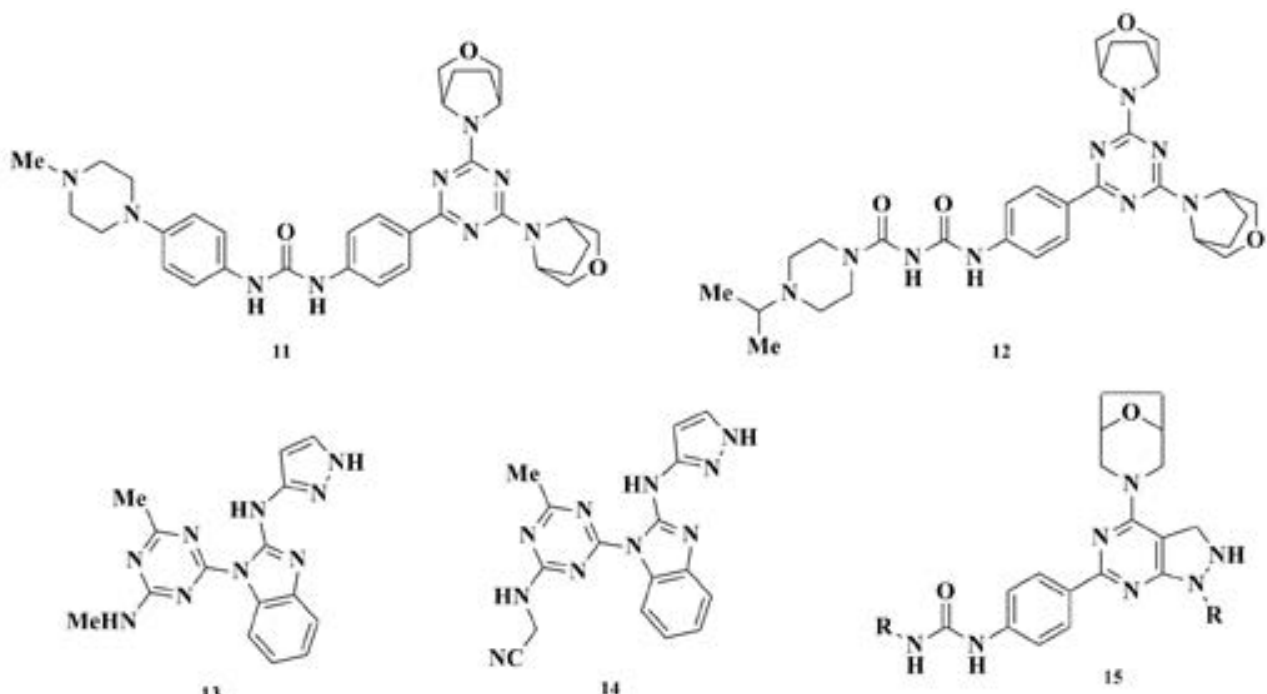

13

14<smiles></smiles>

18

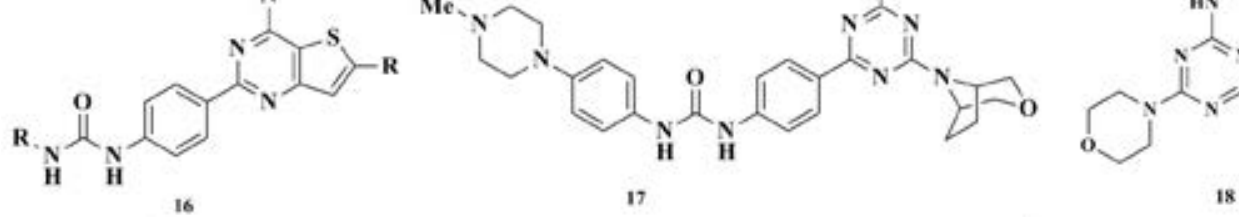<smiles>Cc1cccc2cc[nH]c12</smiles><smiles>CC1CO[C@@H](C)CN1</smiles><smiles>CCCC(=O)c1nc(N2CCOCC2)nc(-n2ccnc2C)n1</smiles><smiles>C=C(NC(=O)c1ccc(-c2nc(I)nc(N3CCOC[C@H]3C)n2)cc1)C(=O)Nc1cccnc1</smiles><smiles>CC1COCCN1C</smiles><smiles>C[C@@H]1COCCN1c1nc(I)nc(-c2ccc(NC(=O)Nc3cccnc3)cc2)n1</smiles><smiles>COc1cc(C=Nc2nc(N3CCOCC3)nc(N3CCOCC3)n2)cc(OC)c1O</smiles><smiles>C1COCCN1</smiles><smiles>CCCCc1cc(C)nc(CCCC)c1</smiles>

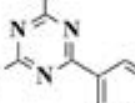

23

Figure 6: mTOR inhibitors. 
$\mu \mathrm{M}$, which were 190, 5 and 6 fold active with compound $22(9.51,29.25$, and $36.20 \mu \mathrm{M})$, respectively.

\section{1, 3, 5-triazine derivatives targeting both PI3K and mTOR}

More than $50 \%$ of all solid tumors lead to up regulated PI3K/Akt/ mTOR signaling due to gene mutations, deletions, or amplifications. Therefore, it is just an innovative strategy for cancer treatment targeting both PI3K and mTOR kinase to inhibit the PI3K/Akt/mTOR signaling pathway [60]. Dual PI3K/mTOR inhibitors likely generate greater therapeutic advantages in cancer patients because of that the retroaction of PI3K signaling aroused by selective mTORC1 inhibitors was alleviated.

Dual PI3K/mTOR inhibitor 25 (Figure 7) showed inhibition of mTOR substrate 4EBP1 phosphorylation in a Lantha-Screen enzyme test $\left(\mathrm{IC}_{50}=97 \mathrm{nM}\right)$, it also showed moderately inhibition of downstream 4EBP1 phosphorylation and mTORC2 downstream AKT phosphorylation in two U-87 cellular assays [11]. PKI587(PF-05212384, 26) (Figure 7) is a dual PI3K-mTOR inhibitor (PI3Ka, PI3K $\gamma$ and mTOR, IC $_{50}$ values of $0.4,5.4$ and $1.6 \mathrm{nM}$, respectively) emerged recently possessing highly similar structure to previously known PI3K-mTOR dual inhibitor PKI-402 (Figure 7) $\left(\mathrm{PI} 3 \mathrm{Ka}, \mathrm{PI} 3 \mathrm{~K} \gamma\right.$ and $\mathrm{mTOR}, \mathrm{IC}_{50}$ values of $1.4,9.2$ and $1.7 \mathrm{nM}$, respectively) with a triazolopyrimidine scaffold [14]. PKI-587 showed complete inhibition of Akt phosphorylation in tissue culture at $30 \mathrm{nM}$ and completely inhibited Akt phosphorylation for 36h injected PKI587 at $25 \mathrm{mg} / \mathrm{kg}$ in MDA-MB361 xenografts experiments. Maximum anti-tumor efficacy was showed at $10 \mathrm{mg} / \mathrm{kg}$ in dose-response analysis. Inhibition of xenograft tumor growth and Akt phosphorylation were also exhibited in H1975 (non-small cell lung cancer), HCT116 colon carcinoma, and U87 (glioma) models [36].<smiles>N#CCNc1ncnc(-n2c(Nc3cccc(O)c3)nc3ccccc32)n1</smiles>

25<smiles>CCn1nnc2c(N3CCOCC3)nc(-c3ccc(NC(=O)Nc4ccc(C(=O)N5CCC([N+](C)(C)C)CC5)cc4)cc3)nc21</smiles>

PKI-402(27)<smiles>[Y19]N(CCN(C)C)C(=O)c1ccc(NC(=O)Nc2ccc(-c3nc(OC4CCOC4)nc(N4CCOCC4)n3)cc2)cc1</smiles>

29<smiles>CN(C1CCN(C(=O)c2ccc(NC(=O)Nc3ccc(-c4nc(N5CCOCC5)nc(N5CCOCC5)n4)cc3)cc2)CC1)C(C)(C)C</smiles>

PKI-587(26)<smiles>O=C(Nc1ccncc1)Nc1ccc(-c2nc(N3CCOCC3)nc(N3C4CCC3COC4)n2)cc1</smiles>

PKI-179(28)<smiles>CN(C)S(=O)(=O)Nc1cc(Nc2ncc(Cl)cc2-c2nc(N)nc(C(C)(C)C)n2)cnc1Cl</smiles>

Figure 7: $\mathrm{PI} 3 \mathrm{~K} / \mathrm{mTOR}$ dual inhibitors 
PKI-179 (Figure 7) is an orally efficacious PI3K/mTOR dual inhibitor obtained from replacing one of the bis-morpholines in PKI587 with 3 -oxa-8-azabicyclo $(3,2,1)$ octane reducing the molecular weight. PKI-179 exhibits significant cell activity in vitro and potent effect in the MDA-361 xenograft model in vivo. Its reaction on other tumor models is on investigating.

Christoph et al. reported that compound 29 (Figure 7) was analogous to clinical candidate PKI-587 and superior to that of preclinical candidate PKI-402 in vitro profile [60]. Furthermore, compound 29 was more potent than compound PKI-402 in vivo biomarker studies while less puissant than PKI-587. More results obtained from the modification effort of 29 will be reported later.

Compound 30 (Figure 7) was reported by Ryan et al. in a U87MG cellular test evaluating phosphorylation of Akt. It displayed good oral biological availability in rats $($ Foral $=63 \%$ ) and low double digit nanometer $\mathrm{IC}_{50}$ [61]. It phosphorylated Akt in dose-dependent reduction in a U87 tumor pharmacokinetics model with $\mathrm{EC}_{50}=193$ $\mathrm{nM}$ in plasma.

\section{1, 3, 5-triazine derivatives targeting RTK}

EGFR inhibitors: Receptor tyrosine kinases (RTK) is indispensable for a numerous biological processes. This includes propagation of antigenic signals derived from tumor-secreted growth factors [62]. The members of vascular endothelial growth factor receptor (VEGFR) tyrosine kinase family are recognized as RTKs to be acted in tumor angiogenesis [63]. The EGFR as a prominent mediator of survival and cell proliferation, leads to survival and improved proliferation of cancer cells [64]. The regulated EGFR molecular-targeted inhibitor is a promising cancer treatment, especially the therapy of lung cancer [65]. Small molecule kinase inhibitors have been discovered as a potential substance to inhibit EGFR since 1980s [66].<smiles>CC(C)N(Cc1ccccc1)c1nc(O)nc(Nc2ccc3ncsc3c2)n1</smiles>

31<smiles>CN(C)c1nc(NCCc2cc(Br)c(O)c(Br)c2O)nc(Nc2ccc(F)cc2)n1</smiles>

Compound 31 (Figure 8) was a potent VEGF-R2 (flk-1/KDR) tyrosine kinase inhibitor. It showed low nanometer potency in the in vitro enzyme inhibition assay $\left(\mathrm{IC}_{50}=18 \mathrm{nM}\right)$ and submissively inhibitory activity in a KDR-induced MAP kinase autophosphorylation assay in HUVEC cells $\left(\mathrm{IC}_{50}=280 \mathrm{nM}\right.$ ), and also exhibited good selectivity against a panel of growth factor receptor tyrosine kinases in vitro. Furthermore, 31 demonstrated anthropogenic activity in an aortic ring explant assay through blocking endothelial outgrowths in rat aortas with an $\mathrm{IC}_{50}$ of $1 \mu \mathrm{M}[6]$.

Mutations in the tyrosine kinase domain of EGFR have been defined as a resistance cause of non-small cell lung cancer (NSCLC). The T790M mutation seems to play a double role in the survival of lung cancer cells [67]: it can not only increase the affinity of the EGFR to ATP comparing with its affinity to EGFR tyrosine kinase inhibitors (EGFRTKIs) [68] especially in combination with the L858R mutation, but also confer growth advantage to the cancer cells [67]. Therefore, it is urgent to promote novel potent selective reversible inhibitors against EGFR with T790M/L858R mutations or dual-effective inhibitors against both WT EGFR and mutant EGFR (T790M/L858R). Compound 32 (Figure 8) was regarded as the most potential selective hit and could highly suppress mutant EGFR enzyme with $\mathrm{IC}_{50}$ of $1.5 \mu \mathrm{M}$ and $\mathrm{IC}_{50}>100 \mu \mathrm{M}$ for WT (wild type) EGFR [69]. Compound 33 (Figure 8) exhibits 'dual-effective' inhibition efficiency against EGFR and mutant EGFRT790M/L858R simultaneously. It demonstrates inhibition against the proliferation of NCI-H1975, A431 and A549 cell lines. Compound 33 potently inhibit the mutant EGFR-dependent, A431 and A549 cell line with $\mathrm{IC}_{50}$ values of $10.5 \pm 0.9 \mu \mathrm{M}, 8.0 \pm 1.6 \mu \mathrm{M}$ and $7.7 \pm 1.3 \mu \mathrm{M}$ respectively [69].

The selectivity of new EGFR inhibitors with the triazine group would most probably be achieved by exploiting the additional hydrophobic pocket located in the back of the ATP-binding site, and the linker between the scaffold and substituents was different from<smiles>COc1nc(NCCN2CCOCC2)nc(Nc2ccc(Cl)cc2)n1</smiles> 
the other triazine analogs, its selective inhibition was still potent. This was consistent with previous prospects of other researches on selective inhibitors against kinases [69].

RTK Tie-2 inhibitors: Tie-2 as an endothelial cell specific receptor tyrosine kinase is involved in angiogenesis course such as remodeling, stability, vessel branching, maturation, and sprouting [70,71]. The suppressant of angiogenesis can restrict tumor survival and growth. The RTK Tie-2 is essential for angiogenesis progress and vessel maturation, and it is exhibited nearly exclusively in the vascular endothelium [72]. Nevertheless, it is difficult to say of Tie-2 signal in tumor angiogenesis. It is necessary to screen a selective small molecule Tie-2 suppressant with selective activities against other kinases that acts in tumor angiogenesis in order to assess the usefulness of direct inhibition of Tie-2 signaling as an anticancer drug. Compared with the plethora of VEGFR-2(KDR), there are two previous small molecule Tie- 2 inhibitors that are highly discriminating than KDR are reported $[73,74]$.

In 2007, Brian et al. disclosed a new series of selective and potent Tie-2 suppressants with pyridine triazine [72]. When administered in i.v and p.o means, compound 34 (Figure 9) demonstrated good pharmacokinetics properties. This compound possessed more than 30 times selective over all screened kinases over enzymatic assays and was valid in a Tie- 2 autophosphorylation cellular test $\left(\mathrm{IC}_{50}=62 \mathrm{nM}\right)$. When the dosage of oral to $100 \mathrm{mg} / \mathrm{kg}$, it inhibited the $94 \%$

phosphorylation of Tie-2 in order to basal at the $3 \mathrm{~h}$ time point in a mouse pharmacogenetics research. The huge selectivity, PK properties and cellular potency of 34 made it play an important role in angiogenesis and tumor progression.

\section{1, 3, 5-triazine derivatives targeting FAK}

Focal adhesion kinase (FAK) as an omnipresent non-receptor tyrosine-protein kinase, which plays as a significant modulator in angiogenesis generally conserved and localized in focal adhesions, is activated by downstream binding integral to the extracellular matrix (ECM) or up-growth factor stimulation [75]. FAK plays a noteworthy role through regulating cancer cells and their microenvironments in tumor progression and metastasis. Overexposure or increasing activity of FAK is common in many human cancers [76]. Therefore, FAK was considered as a potential target for cancer therapy at present because it is highly expressed at both the transcriptional and translational level in numerous cancers [77].
Several FAK inhibitors affected glioma, ovarian tumor growth and neuroblastoma in vivo have been successfully developed, owing to their ability to suppress tumor-associated angiogenesis and tumor growth competitively. As FAK inhibitors, a novel series of diarylamino-1, 3, 5 -triazine derivatives (Figure 10) were reported by Dao et al. which demonstrated deleterious effects on endothelial cell viability essentially and the best of our depressants showed a comparable potency on cell activity at significantly low concentration. PHM16 (Figure 10) available inhibited FAK autophosphorylate at in HUVEC cells, indicating it could potently block FAK signaling route in living cells [78].

\section{1, 3, 5-triazine derivatives targeting CDK}

Cyclin-dependent kinases (CDKs) take critical effect on regulating cell cycle machinery [79]. The cycling mediator subunit is necessary for activating these family kinases, and each phase of the cell cycle is achieved by different CDK/cyclin pairs [80]. Until now, no less than 9 CDKs and at least 12 diverse cyclin families have been evaluated. CDK1/cyclin B, CDK2/cyclin A, CDK2/ Cycling E, CDK4/cyclin D, and $\mathrm{CDK} 6 /$ cyclin $\mathrm{D}$ as the remarkable CDKs/cyclins for central cell cycle function have been demonstrated [81]. Furthermore, CDK5 may play a significant role in Alzheimer's pathology and neurogenesis, as its activity is supreme in brain $[82,83]$. However, CDK7, CDK8, and CDK9 have been invovled in the regulation of RNA elongation [84]. It is a common feature for uncontrolled CDK activity with increasing evidence interrelated to proliferative diseases such as psoriasis, cancer and restenosis, and many CDK inhibitors have been investigated over the past decade [85-91].

Compound 39 (Figure 11) indicates moderate CDK1 inhibitory potency $\left(\mathrm{IC}_{50}=2.4 \mu \mathrm{M}\right)$. A novel potent $\mathrm{CDK}$ inhibitor is 40 (Figure 10) competitively inhibited CDK1 $\left(\mathrm{IC}_{50}=0.021 \mu \mathrm{M}\right), \mathrm{CDK} 2$, and CDK5, and showed submissively efficacy of CDK4, CDK6, and CDK7, which also exhibited significant potential of GSK-3 $\beta$. It potently inhibited the proliferation of various tumor cell-lines including A375, U937, HCT116 and HeLa. Compound 40 produced an effective survival increase to nude mice in human A375 xenografts models when administered at 150 and $125 \mathrm{mg} / \mathrm{kg}$ intraperitoneally [7]. An illustration of the binding mode of compound 40 in the ATP-binding site of CDK1 is proposed by molecular docking (Figure 12). Compound 40 fits well into the ATPbinding site of CDK1 and makes extensively favorable van der Waals contacts with the binding site through its primary scaffold [7].<smiles>CN(CCCN(C)C(C)(C)C)c1ccc(C(F)(F)F)cc1NC(=O)c1cc(Oc2ncccc2-c2ncnc(NC(C)(C)C)n2)ccc1F</smiles> 


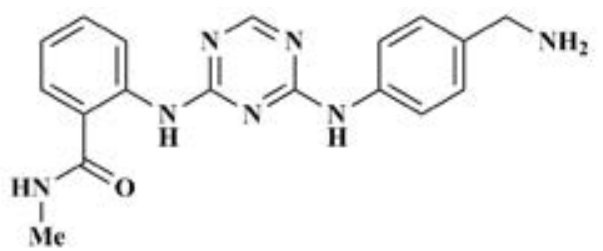

35<smiles>CNc1nc(Nc2cc(OC)c(OC)c(OC)c2)nc(Nc2ccccc2S(=O)(=O)NC)n1</smiles>

37

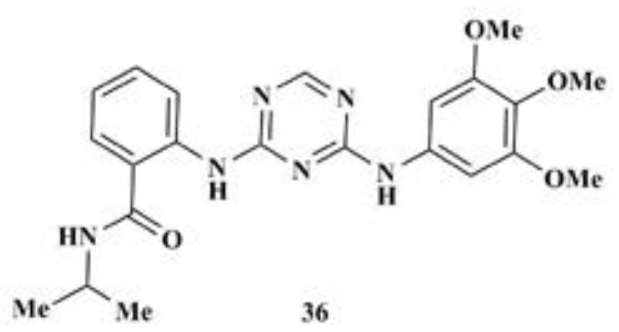<smiles>COc1cc(Nc2ncnc(Nc3ccccc3C(=O)N[Na])n2)cc(OC)c1O</smiles>

38

Figure 10: FAK inhibitors.<smiles>OCCCNc1cncc(-c2cc(Nc3cccc(Cl)c3)ncn2)c1</smiles>

39<smiles>OCCCNc1cc(-c2ncnc(Nc3cccc(Cl)c3)n2)ccn1</smiles>

40

Figure 11: CDK inhibitors.

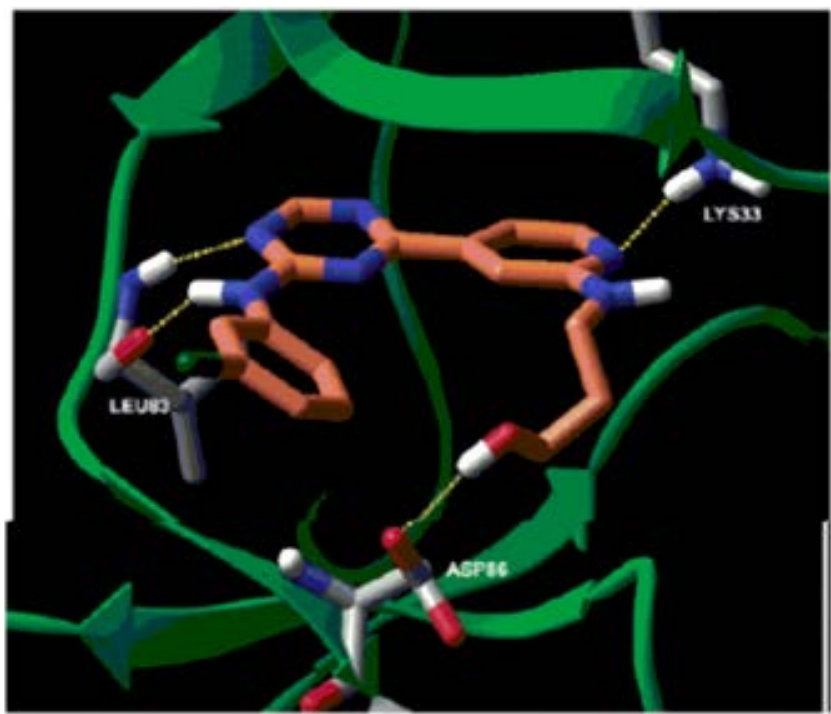

Figure 12: Binding mode of compound 66 with CDK1. The key $\mathrm{H}$ bonds formed between compound 66 and CDK1 are indicated by the yellow dotted lines. 


\section{1, 3, 5-triazine derivatives targeting ROCK}

Rho-associated protein kinases (ROCKs) belong to Ras superfamily are primary and excellent downstream regulators of the Rho GTPbinding proteins that mutation in nearly $30 \%$ of all human cancers has been discovered [92]. ROCKs play a role in different cellular functions, smooth muscle striation, cell attachment and motility, acting in cytoskeleton organization, and gene expression [93]. ROCK1 and ROCK2 isoforms have a high degree of sequence homology particularly in the catalytic kinase region (89\% identity) [94]. The expression of ROCK1 primarily exists in liver, lung, kidney, spleen and testis, while ROCK2 generally exists in the heart and brain [95]. Fasudil (Figure 13) is the exclusive ROCK inhibitor used to prevent cerebral vasospasm after subarachnoid hemorrhage in clinical in Japan although some available ROCK inhibitors are in clinical trials at present [96-99]. Therefore, it is quite necessary to identify and design novel ROCK1 inhibitors to develop novel therapies.

Recently, Shen investigated a new ROCK1 inhibitor with the triazine group (Figure 13) by screening a small-scale compounds library [100]. This inhibitor not only prominently inhibited ROCK1 activity. But also excellently inhibited the proliferation of several cancer cell lines. Inhibitor 42 inhibit the ROCK1 kinase with $\mathrm{IC}_{50}$ of $11.2 \mu \mathrm{M}$, it can also effectively inhibit the cell multiplication of A549, H460, LP1 and OPM-2 with $\mathrm{EC}_{50}$ values lower than $15 \mu \mathrm{M}$ suggests that this inhibitor is worthy of more study. Compound 43 is likewise a potent ROCK1 inhibitor with the $\mathrm{IC}_{50}$ of $6 \mu \mathrm{M}$.

ROCK1 inhibitors with 1, 3, 5-triazine scaffold showed best binding affinity to Rho-associated protein kinases that the van der Waals interaction is the major driving force for ligand binding. Small hydrophobic groups may be favorable to enhance the nonpolar interactions with ROCK1. The hydrogen binding interaction important residues for achieving strong binding was highlighted. Moreover, Asp160, Ile82, Val90, Met156, Leu205 and Phe363 are all hydrophobic residues, and they play key roles in inhibitor-protein interactions which afford important guidance for the rational design of novel ROCK inhibitors [100].

\section{1, 3, 5-triazine Derivatives on other Targets}

\section{1, 3, 5-triazine derivatives targeting PAK4}

p21-activated kinases (PAKs) are members of ste20 serine/ threonine kinases that are regulated by Rho-GTPases [101]. PAK4 has been widely demonstrated to regulate cell morphology, cytoskeleton organization, cell proliferation, migration, and survival [102-104]. Moreover, the improved expression and activity of PAK4 in multiple human tumor cell lines suggest that targeting PAK4 is viable in the anticancer drug development. A novel PAK4 inhibitor, KY-04031(Figure 14) inhibits PAK4 activity $\left(\mathrm{IC}_{50}=0.79 \pm 0.05 \mu \mathrm{M}\right)$ and prostates cancer cell growth and invasion. The unique molecular feature of KY-04031 can be utilized in developing new PAK4 inhibitors [105].

\section{1, 3, 5-triazine derivatives targeting Hsp90}

An ATP-dependent molecular chaperone, named Heat shock protein 90 (Hsp90) serves as a crucial participant in regulating many proteins which involved in signaling pathway and cell proliferation $[106,107]$. In humans, Hsp90 has two cytologic isotherms, Hsp90a (irreducible form) and Hsp90 $\beta$ (constitutive form), and the functional differences between these isotherms are poorly understood. Recent studies showed that cancer cells need secretion of Hsp90a into the extracellular matrix for invasion and metastasis [108]. Once identified as one of the most abundant intracellular proteins in 1987, Hsp90 has received considerable attention and emerged as an attractive cancer therapeutic target owing to its chaperoning function of the substrate proteins. In this regard, the inhibition of Hsp90's chaperoning function can induce simultaneous blockage of several signaling pathways in tumor cells, so as to defeat the inevitable drug resistance of conventional cancer therapeutic agents [109].

A novel series of 2-amino-1, 3, 5-triazines bearing a tricyclic moiety as Hsp90 inhibitors are described by Atsushi [110]. Starting from lead CH5015765 (Figure 15) and natural Hsp90 inhibitor geldanamycin (Figure 15), they identified $\mathrm{CH} 5138303$ (Figure 15) in order to optimize affinity to Hsp90, in vitro cell growth inhibitory activity, water solubility, and liver microsomal stability of inhibitors. Compound 47 displayed superior binding affinity to N-terminal of Hsp90a $\left(\mathrm{K}_{d}=0.52\right.$ $\mathrm{nM}$ ) and excellent cell growth inhibition for human tumor cell-lines in vitro (HCT116 $\left.\mathrm{IC}_{50}=0.098 \mu \mathrm{M}, \mathrm{NCI}-\mathrm{N} 87 \mathrm{IC}_{50}=0.066 \mu \mathrm{M}\right)$. Its oral bioavailability in mice $(\mathrm{F}=44.0 \%)$ was very important. It also had $136 \%$ inhibition in a human NCI-N87 gastric cancer xenograft model.

\section{1, 3, 5-triazine derivatives targeting hCA IX and hCA XII}

Carbonic anhydrases (CA) are ubiquitous metalloenzymes that involved in various physiological and pathological processes, serving as an important target for designing drugs useful in diseases like epilepsy and cancer [111-115]. Recent research has shown that several CA isozymes are drug targets for cancer and infective diseases. There are 11 active CA isozymes known in human [116,117]. Tumour-associated CAs are recognized as hCA IX and hCA XII (also hCA XIV). It is generally a poor prognosis sign that this protein expression in many types of solid tumors, such as mesotheliomas, ependymomas/gliomas,<smiles>O=S(=O)(c1cccc2cnccc12)N1CCCNCC1</smiles>

fasudil(41)<smiles>Nc1nc(CN2CCN(c3ccccc3F)CC2)nc(Nc2cccc3ccccc23)n1</smiles>

42

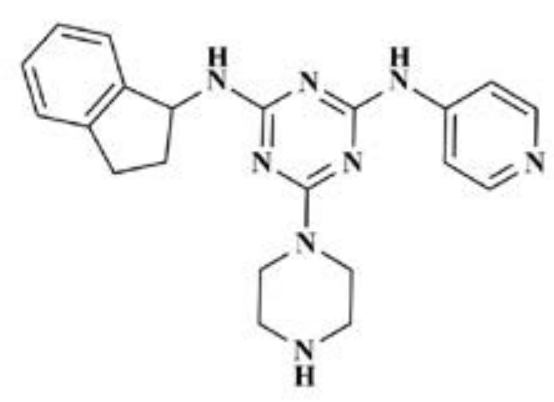

43

Figure 13: ROCK1 inhibitors. 
<smiles>COc1nc(NCCc2c[nH]c3ccccc23)nc(Nc2ccc3[nH]ncc3c2)n1</smiles>

KY-04031(44)

Figure 14: PAK4 inhibitors

follicular/papillary carcinomas [118-122]. Like CA IX, CA XII is also existing in several tumors, but CA XIV is commonly exist in some tissues like the liver, kidneys and brain among many others [123]. It is also proved that potent CA IX inhibitors generated in the laboratory give rise to a lower acidifying effects in transacted or cultured tumor cells. Inhibition of the tumor-associated CAs may be a potent therapeutic method to treat with hypoxia tumors, which are better than all the traditional chemotherapeutic agents or radiation [124]. Recent studies show that it is a novel therapeutic therapy for cancer targeting CA IX/XII [120-122].

The most available and selective hCA IX inhibitors received until now introducing triazinyl moieties to sulfonamides were previously reported by Garaj et al. [125]. In 2011 Carta et al. showed a series of new compounds introducing triazinyl with amino acyl/hydroxylalkylamino moieties and they were transmembrane inhibitors with low nanometer [125]. The tumor-associated isoform hCA IX was inhibited by compounds 48,49 (Figure 16) with $\mathrm{K} 1 \mathrm{~s}<1.0 \mathrm{nM}$ but the hCA XII was not well understood earlier with these derivatives.

Amrita and co-workers have reported sulfonamide and sulfamate CAIs to show anti-tumour activity in vitro and in vivo when targeting CA IX/XII [116]. They reported earlier that incorporation of a 1, 3, 5-triazine moiety in 4-aminobenzene sulfonamide scaffold leads to compounds with enhanced efficacy and specificity with K1s in the range of 1.2-34.1 nM against hCA IX and of 2.1-33.9 nM against hCA XII, respectively [126]. Compounds 50-54 (Figure 16) showed inhibition constants $\mathrm{K} 1$ ranging from 1.2 to $5.9 \mathrm{nM}$ [116].

\section{1, 3, 5-triazine derivatives as Enolase inhibitors}

Enolase is an ingredient of the glycolysis pathway and it is a key in diverse cellular processes. Cancer cells producing ATP increased depending on glycolysis are named Warburg effect [127]. The metabolic alteration is the fundamental difference between cancer and normal cells. Glycolysis inhibitors can kill cancer cells selectively and also can cause cancer cell death in a hypoxic environment more effectively $[128,129]$.

Small molecule "ENOblock" (Figure 17) are the first, nonsubstrate analogue reported by Jung et al., it directly binds to enolase with inhibitory activity [130]. Small molecule screened in a cancer cell test can isolate ENOblock. In hypoxic conditions, it's used to detect cytotoxic agents. The inhibition of ENOblock for tumor cell metastasis in vivo indicated by further analysis. Biochemical analysis showed that ENOblock inhibited enolase with $\mathrm{IC}_{50}$ of $0.576 \mu \mathrm{M}$. ENOblock makes people understand cancer better. It is imperative to explore novel glycolysis inhibitors with 1,3,5-triazine for cancer therapy is urgently [128].

\section{1, 3, 5-triazine derivatives as microtubules inhibitors}

Microtubules are primary components of cytoskeleton formed by tubulin molecules in eukaryotic cells, which related with various remarkable cellular pathway as mitosis. Microtubules played a major role in the mitotic spindle build process, revealing it as a potential target for antitumor treatment [131-133]. Although the range of antimitotic agent is extremely large, only few agents received clinical and commercial success up to present [134-139]. Poor therapeutic indexes and other unrecognized factors made the failure of these molecules [91].

Moon et al. reported compound 56 (Figure 18) is a microtubule destabilizing agent with potent growth inhibition against U936 cells $\left(\mathrm{GI}_{50}=1 \mu \mathrm{M}\right)$ [140]. Tubulyzine (Figure 18) is a trisubstituted 1, 3, 5-triazine derivative with potent microtubule disassembly properties [141]. Inhibitor 58 (Figure 18) was published by Yulia et al., and the speed of assembly and the final amount of microtubules were higher under control experiment than in the presence of 58 [142]. Compound 58 demonstrated the optimal combination of tubulin binding activity and antiproliferative $\left(\mathrm{IC}_{50}=0.687 \pm 0.013 \mu \mathrm{M}\right)$ according to the best spacer in tubulin-binding units.

\section{1, 3, 5-triazine derivatives as Rad6B inhibitors}

Recently, the highly-regulated ubiquitin-proteasome system is a modish target for anticancer therapy in charge of degradation $>80 \%$<smiles>Nc1nc(S[AlH2])nc(C2=C3C=CC=C4COCC(C=C2Cl)C43)n1</smiles>

CH5015765(45)

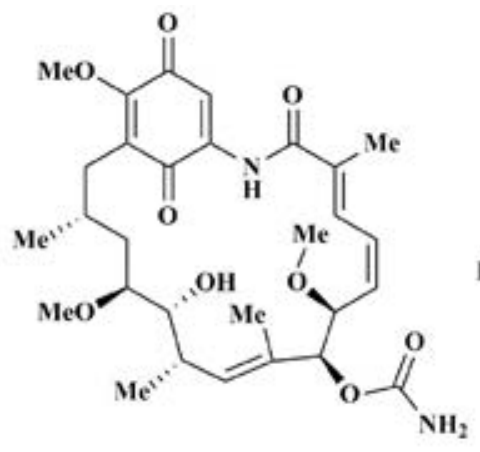

geldanamycin(46)<smiles>NC(=O)CCCSc1nc(N)nc(C2=C3C=CC=C4COCC(C=C2Cl)C43)n1</smiles>

CH5138303 (47)

Figure 15: Hsp90 inhibitors. 
<smiles>CC(Nc1nc(Cl)nc(-c2ccc(S(N)(=O)=O)cc2)n1)C(=O)O</smiles>

48<smiles>NS(=O)(=O)c1ccc(-c2nc(Cl)nc(NCCO)n2)cc1</smiles>

49<smiles>Nc1nc(N)nc(Nc2ccc(OS(N)(=O)=O)cc2)n1</smiles>

50<smiles>CN(CCO)c1nc(Cl)nc(Nc2ccc(OS(N)(=O)=O)cc2)n1</smiles>

51

52

53<smiles>NCCCNc1nc(NCCCN)nc(Nc2ccc(S(N)(=O)=O)cc2)n1</smiles>

Figure 16: hCA IX / hCA XII inhibitors<smiles>NCCOCCOCCNC(=O)Cc1ccc(Nc2nc(NCc3ccc(F)cc3)nc(NCC3CCCCC3)n2)cc1</smiles>

ENOblock(55)

Figure 17: Enolase inhibitor.

cellular proteins [143]. Three successive classes of enzymes namely E1, E2, E3 can enhance mechanistic and structural class multiformity regulate the ubiquitousness of protein. It is reported that the E2 enzyme Rad6B plays a key role in post-replication DNA repair, overexpression in breast tumor cell lines. The over-expression of Rad6B is constitutive in nontransferable cells due to induct cancer phenotypic changes such as aneuploidy, centrosome amplification and abnormal mitosis [144]. Conjugates are insensitive to professional degradation due to the ability of Rad6B to ubiquitous $\beta$-catenin. The consequent activation and stabilities of oncogenes $\beta$-catenin further confirmed that Rad6B is a therapeutic target particularly in breast cancer [145].

TZ8 (Figure 19) and TZ9 (Figure 18) were formerly reported Rad6B-inhibitory anticancer agents MDA-MB-231 cells [146]. The triazine carboxamide (Figure 19) was the highest active compound against MCF-7 cell line. From molecular docking studies, TZ8 and compound 61 were incorporated deep inside the Rad6B binding pocket, making key interactions between the hydrazine nitrogen atoms and the Rad6B active site residues Cys88 and Asp90 (Figure 20) [147]. 


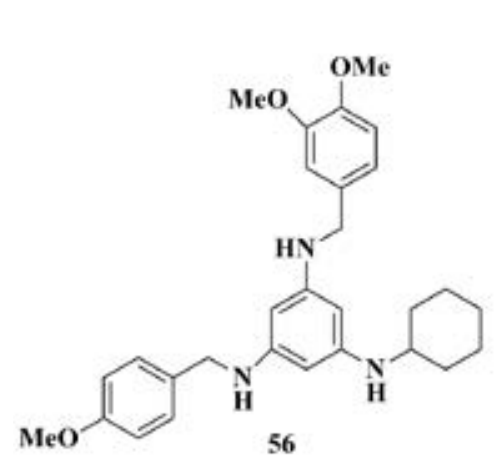<smiles>COc1ccc(CNc2nc(NCc3ccc(OC)cc3)nc(NC3CCCCC3)n2)cc1</smiles><smiles>C=C1C=C2C(=CC=C1C)C(OC)c1c(cc(OC)c(OC)c1OC)CC[C@@H]2NC(=O)CCn1cc(CCCCCCCCNc2nc(NCc3ccc(OC)cc3)nc(NCc3ccc(OC)cc3)n2)nn1</smiles>

Figure 18: Microtubules inhibitors.

$\mathbf{R}$<smiles>Nc1nc(COC(=O)c2ccc(Cl)cc2)nc(Nc2ccc([N+](=O)[O-])cc2)n1</smiles>

$59 \mathrm{TZ} 8(\mathrm{R}=\mathrm{Me})$ $60 \mathrm{TZ9}(\mathrm{R}=\mathrm{H})$<smiles>COc1ccc(Nc2nc(N)nc(C(=O)NCc3ccccc3OC)n2)cc1</smiles>

61

Figure 19: Rad6B inhibitors.
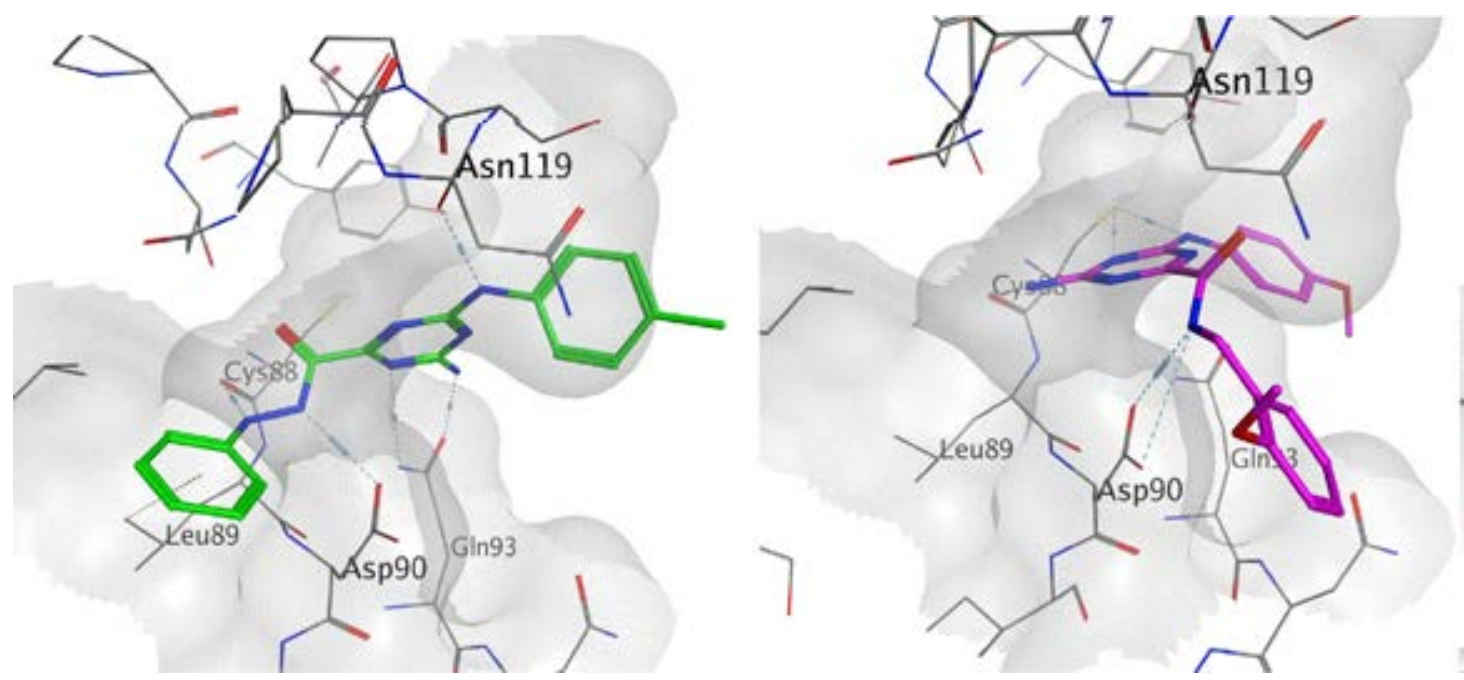

Figure 20: Docking interactions of TZ8 and compound 61 in the Rad6B active site. 
The cell line activity profile and molecular modelling studies confirmed that Rad6B is a possibility mechanistic target for cancer treatment.

\section{1, 3, 5-triazine derivatives as HDACs inhibitors}

Inhibition of histone deacetylases (HDACs) has been identified as a unique mechanism for cancer chemotherapy. 1, 3, 5-triazine-based hydroximic acids are as novel HDAC inhibitors due to the present work. Compound 62 (Figure 21) was a potent inhibitor of human histone deacetylases exhibited significant antiproliferative effect on HCT-116, MCF-7, and HeLa cancer cell lines. DNA flow cytometric analysis revealed that compound 62 induced apoptosis and cell cycle arrest at G2/M phase in HCT-116 cells [148].

\section{1, 3, 5-triazine derivatives as Cytotoxic agents}

It is utmost important to development of novel anticancer drugs and more effective treatment strategies for cancer as traditionally prescribed chemotherapeutic agents have problems with toxicity and drug resistance [149]. Despite the fact that, many kinase inhibitors have been discovered recently and some of them have been successfully developed for cancer therapy still there is urgent demand for discovery of improved cytotoxic agents. Because of most solid human cancer tumor are multi causal in nature and their treatment with "mechanism based" agents lonely is unlikely to be successful, so a combination of these inhibitors with a better cytotoxic drug seems to be a good strategy [150].

Cytotoxicity of 1, 3, 5-triazine derivatives is well known as
Hexamethylmelamine (HMM) (Figure 22) as an effective agent against breast, lung and ovarian cancer with many adverse effects [151]. Irsogladine (Figure 22) has been shown to have anti-tumor activity in murine xenograft models of epidermoid cancer and glioma [152]. More recently, the effect of compound 64 was also investigated in a human breast cancer athymic nude mouse system and the results suggested that irsogladine can be useful in the breast cancer adjuvant setting [153]. R. Kumar et al. described a series of (tetrahydro- $\beta$-carboline)- 1 , 3, 5-triazine hybrid molecules showed cytotoxicity against human cancer cell lines and considered as important lead compounds for potential application in anticancer chemotherapy [154]. Compounds 65 (Figure 22) showed potent antiproliferative activities against K562, PC-3, and HO8910 cell lines with $\mathrm{IC}_{50}$ values of $1.01,2.23$, and $1.06 \mu \mathrm{M}$, respectively [4]. Further study of the mechanisms of these compounds in suppression of tumor cells growth is underway.

\section{Clinical Studies}

Various types of antitumor agents with 1, 3, 5-triazines including molecules that inhibit just one target have been disclosed and a few PI3K inhibitors have at present progressed into human clinical trials, such as ZSTK-474 (NCT01280487, Zenyaku Kogyo, phase I), PKI587 (NCT00940498, Pfizer, phase Ib/ II), PKI-179 (Pfizer, phase I) [21,33]. However, no recent development of other compounds for the oral treatment of cancer has been reported for this research.

Whereas, failure to activate the apoptotic programme represents an important mode of drug resistance in tumor cells. The development of<smiles>CC(CC(C)(C)NC(=O)NO)Nc1ccc(-c2nc(N3CCOCC3)nc(N3CCOCC3)n2)cc1</smiles>

Figure 21: HDACs inhibitors.<smiles>CNc1nc(N(C)C)nc(N(C)C)n1</smiles>

63<smiles>Nc1nc(N)nc(-c2cc(Cl)ccc2Cl)n1</smiles>

Figure 22: Cytotoxic agents with 1, 3, 5-triazines.<smiles>Cc1ccc(Nc2nc(-c3ccccc3)nc(N3CCNCC3)n2)cc1</smiles>

65 
resistance to therapy is an important clinical problem which limits the use of triazines as anti-tumor agents [53].

\section{Conclusion}

This review presents the most recent advances in the development of various 1, 3, 5-triazine compounds as anticancer drugs. The present review is expected to provide drug designers and medicinal chemists integrative targeting information of 1, 3, 5-triazine derivatives to improve clinical viable anticancer molecules. From the known inhibitors, we notice that introducing structural units of various acrylamide, sulfonamide, morpholine, pyrimidyl, piperazine groups into the 1,3,5-triazine scaffold could improve antitumor activity, but pharmacokinetics properties need to be improved via biotransformation for clinical use. More anticancer inhibitors with 1, 3, 5 -triazine scaffold would be prepared from different sources and their modes of action would be ascertained not long after.

\section{Acknowledgements}

This work received the support of the National Natural Science Foundation of China (No. 81273476). The authors of this manuscript acknowledge the Innovative Research Team of the Ministry of Education and Program for Liaoning Innovative Research team in University for providing financial assistance.

\section{References}

1. Zhao H, Liu Y, Cui Z, Beattie D, Gu Y, et al. (2011) Design, synthesis, and biological activities of arylmethylamine substituted chlorotriazine and methylthiotriazine compounds. J Agric Food Chem 59: 11711-11717.

2. Kosary I, Kosztreiner E, Rabloczky G, Kurhy M (1989) Synthesis and cardiotonic activity of 2,4-diamino-1,3,5-triazines. Eur J Med Chem 24: 97-105.

3. Kreutzberger A, SchIÃafer I (1988) [Central depressive substances. 7. Nuclear substituted (diallylamino)-,3,5-triazines].Arch Pharm (Weinheim) 321: 827-830.

4. Hu Z, Ma T, Chen Z, Ye Z, Zhang G, et al. (2009) Solid-phase synthesis and antitumor evaluation of 2,4-diamino-6-aryl-,3,5-triazines.J Comb Chem 11: 267-273.

5. Zheng M,Xu C, Ma J, Sun Y, Du F, et al. (2007) Synthesis and antitumor evaluation of a novel series of triaminotriazine derivatives.Bioorg Med Chem 15: $1815-1827$

6. Baindur N,Chadha N, Brandt BM, Asgari D, Patch RJ, et al. (2005) 2-Hydroxy4,6-diamino-[,3,5]triazines: a novel class of VEGF-R2 (KDR) tyrosine kinase inhibitors.J Med Chem 48: 1717-1720.

7. Kuo GH, Deangelis A, Emanuel S, Wang A, Zhang Y, et al.(2005) Synthesis and identification of $[1,3,5]$ triazine-pyridine biheteroaryl as a novel series of potent cyclin-dependent kinase inhibitors. J Med Chem 48: 4535-4546.

8. Saczewski F,BuÅ,akowska A, Bednarski P, Grunert R (2006) Synthesis, structure and anticancer activity of novel 2,4-diamino-,3,5-triazine derivatives. Eur J Med Chem 41: 219-225.

9. Saczewski F,BuA,akowska A (2006) Synthesis, structure and anticancer activity of novel alkenyl-,3,5-triazine derivatives.Eur J Med Chem 41: 611-615.

10. Kong D,Yamori T (2007) ZSTK474 is an ATP-competitive inhibitor of class phosphatidylinositol 3 kinase isoforms.Cancer Sci 98: 1638-1642.

11. VenkatesanAM, Dehnhardt CM, Santos ED, Chen Z, Santos OD, et al.(2010) Bis(morpholino-1,3,5-triazine) derivatives: potent adenosine 5'-triphosphate competitive phosphatidylinositol-3-kinase/mammalian target of rapamycin inhibitors: discovery of compound 26 (PKI-587), a highly efficacious dual inhibitor. J MedChem 53: 2636-2645.

12. Yakhontov LN, Vakhatova GM (1981) Search for medicinal preparations in the series of 1,3,5-triazines (review). Pharmaceutical Chemistry Journal 15: 546561

13. Milletti F, Hermann JC2 (2012) Targeted kinase selectivity from kinase profiling data.ACS Med ChemLett 3: 383-386.

14. Wu P, Yongzhou H (2012)Small molecules targeting phosphoinositide 3-kinases. Med ChemCommun 3: 1337-1355.

15. Cantley LC1 (2002) Thephosphoinositide 3-kinase pathway.Science 296 $1655-1657$.
16. Engelman JA,Luo J, Cantley LC (2006) The evolution of phosphatidylinosito 3-kinases as regulators of growth and metabolism. Nat Rev Genet 7: 606-619.

17. Vanhaesebroeck B,Leevers SJ, Panayotou G, Waterfield MD (1997) Phosphoinositide 3-kinases: a conserved family of signal transducers. Trends BiochemSci 22: 267-272.

18. Vanhaesebroeck B,Leevers SJ, Ahmadi K, Timms J, Katso R, et al. (2001) Synthesis and function of 3-phosphorylated inositol lipids.Annu Rev Biochem 70: 535-602.

19. Denley A, Kang S, Karst U, Vogt PK (2008) Oncogenic signaling of class I PI3K isoforms.Oncogene 27: 2561-2574.

20. Maffucci T, Cooke FT, Foster FM, Traer CJ, Fry MJ, et al. (2005) Class I phosphoinositide 3-kinase defines a novel signaling pathway in cell migration.J Cell Biol 169: 789-799.

21. Falasca M,Maffucci T (2007) Role of class II phosphoinositide 3-kinase in cell signalling. Biochem Soc Trans 35: 211-214.

22. Vivanco I, Sawyers CL (2002) The phosphatidylinositol 3-Kinase AKT pathway in human cancer.Nat Rev Cancer 2: 489-501.

23. Sonenberg N, Pause A (2006) Signal transduction. Protein synthesis and oncogenesis meet again.Science 314: 428-429.

24. Vanhaesebroeck B, Ali K, Bilancio A, Geering B, Foukas LC (2005) Signalling by $\mathrm{PI} 3 \mathrm{~K}$ isoforms: insights from gene-targeted mice.Trends BiochemSci 30 : 194-204.

25. Shaw RJ,Cantley LC (2006) Ras, PI(3)K and mTORsignalling controls tumour cell growth.Nature 441: 424-430.

26. Dancey J1 (2010) mTOR signaling and drug development in cancer.Nat Rev ClinOncol 7: 209-219.

27. Wu X,Senechal K, Neshat MS, Whang YE, Sawyers CL (1998) The PTEN/ MMAC1 tumor suppressor phosphatase functions as a negative regulator of the phosphoinositide 3-kinase/Akt pathway.ProcNatlAcadSci U S A 95: 15587 15591.

28. Stambolic V, Suzuki A, de la Pompa JL, Brothers GM, Mirtsos C, et al. (1998) Negative regulation of PKB/Akt-dependent cell survival by the tumor suppressor PTEN.Cell 95: 29-39.

29. Hollander MC, Blumenthal GM, Dennis PA (2011) PTEN loss in the continuum of common cancers, rare syndromes and mouse models.Nat Rev Cancer 11 : 289-301.

30. Liu P, Cheng H, Roberts TM, Zhao JJ (2009) Targeting the phosphoinositide 3-kinase pathway in cancer.Nat Rev Drug Discov 8: 627-644.

31. Marone R,Cmiljanovic V, Giese B, Wymann MP (2008) Targeting phosphoinositide 3-kinase: moving towards therapy.BiochimBiophysActa 1784: 159-185

32. Shuttleworth S, Silva F, Tomassi C, Cecil A, Hill T, et al. (2009) Progress in the design and development of phosphoinositide 3-kinase (PI3K) inhibitors for the treatment of chronic diseases.Prog Med Chem 48: 81-131.

33. Kong D, Okamura M, Yoshimi H, Yamori T (2009) Antiangiogenic effect of ZSTK474, a novel phosphatidylinositol 3-kinase inhibitor.Eur J Cancer 45: 857 865.

34. Yaguchi S, Fukui Y, Koshimizu I, Yoshimi H, Matsuno T, et al. (2006) Antitumor activity of ZSTK474, a new phosphatidylinositol 3-kinase inhibitor.J Natl Cancer Inst 98: 545-556.

35. Berndt A, Miller S, Williams O, Le DD, Houseman BT, et al. (2010) The p110 delta structure: mechanisms for selectivity and potency of new $\mathrm{PI}(3) \mathrm{K}$ inhibitors. Nat ChemBiol 6: 117-124.

36. Rewcastle GW,Gamage SA, Flanagan JU, Frederick R, Denny WA, et al (2011) Synthesis and biological evaluation of novel analogues of the pan class I phosphatidylinositol 3-kinase (PI3K) inhibitor 2-(difluoromethyl)-1-[4,6-di(4 morpholinyl)-,3,5-triazin-2-yl]-1H-benzimidazole (ZSTK474).J Med Chem 54: 7105-7126.

37. Welker ME,Kulik G (2013) Recent syntheses of PI3K/Akt/mTOR signaling pathway inhibitors.Bioorg Med Chem 21: 4063-4091.

38. Smith AL, DAngelo ND, Bo YY, Booker SK,Cee VJ, et al. (2012) Structurebased design of a novel series of potent, selective inhibitors of the class I phosphatidylinositol 3-kinases. J MedChem 55: 5188-5219.

39. Norman MH, Andrews KL, Bo YY, Booker SK, Caenepeel S, et al. (2012) 
Selective class I phosphoinositide 3-kinase inhibitors: optimization of a series of pyridyltriazines leading to the identification of a clinical candidate, AMG 511.J Med Chem 55: 7796-7816.

40. Shuttleworth SJ, Silva FA, Cecil AR, Tomassi CD, Hill TJ, et al. (2011) Progress in the preclinical discovery and clinical development of class I and dual class I/ IV phosphoinositide 3-kinase (PI3K) inhibitors. Curr Med Chem 18: 2686-2714.

41. Winer ES, Ingham RR, Castillo JJ (2012) PCl-32765: a novel Bruton's tyrosine kinase inhibitor for the treatment of lymphoid malignancies. Expert OpinInvestig Drugs 21: 355-361.

42. Meadows SA, Vega F, Kashishian A, Johnson D, Diehl V, et al. (2012) PI3Kס inhibitor, GS-1101 (CAL-101), attenuates pathway signaling, induces apoptosis, and overcomes signals from the microenvironment in cellular models of Hodgkin lymphoma. J Blood 119: 1897-1900.

43. Lannutti BJ, Meadows SA, Herman SEM,Kashishian A, Steiner B, et al. CAL10 , a p110 $\hat{I}^{\prime}$ selective phosphatidylinositol-3-kinase inhibitor for the treatment of B-cell malignancies, inhibits PI3K signaling and cellular viability. Blood. 201, 117(2), 591-594.

44. Ma ZY, Zhang XH, Li C, Zheng Y, Yang G, et al. Design and synthesis of 3 -substitued methylenethiochroman-4-ones-as anticancer agents. Chem. Res. Chinese Universities. 201, 27(5), 787.

45. Pinson JA,Zheng Z, Miller MS, Chalmers DK, Jennings IG, et al. (2013) L-Aminoacyl-triazine derivatives are isoform-selective PI3Kî ${ }^{2}$ inhibitors that target non-conserved Asp862 of PI3Kî²ACS Med Chem Lett 4: 206-210.

46. Guertin DA, Sabatini DM (2007) Defining the role of mTOR in cancer. Cancer Cell 12: 9-22.

47. Chiang GG, Abraham RT (2007) Targeting the mTOR signaling network in cancer.Trends Mol Med 13: 433-442.

48. Yuan TL,Cantley LC (2008) PI3K pathway alterations in cancer: variations on a theme.Oncogene 27: 5497-5510.

49. Verheijen J, Yu K,Zask A (2008) mTOR inhibitors in oncology. Annu Rep Med Chem43: 189-202.

50. Peterson EA,Boezio AA, Andrews PS, Boezio CM, Bush TL, et al. (2012) Discovery and optimization of potent and selective imidazopyridine and imidazopyridazinemTOR inhibitors.Bioorg Med ChemLett 22: 4967-4974.

51. Tanneeru K, Reddy BM, Guruprasad L (2012) Three-dimensional quantitative structure-activity relationship (3D-QSAR) analysis and molecular docking of ATP-competitive triazine analogs of human mTOR inhibitors. Med Chem Res 21: $1207-1217$

52. Verheijen JC, Richard DJ, Curran K, Kaplan J, Yu K, et al. (2010) 2-Arylureidophenyl-4-(3-oxa-8-azabicyclo[3.2.1]octan-8-yl)triazines as highly potent and selective ATP competitive mTOR inhibitors: optimization of human microsomal stability. Bioorg Med Chem Lett 20: 2648-2653.

53. Fresno Vara JA,Casado E, de Castro J, Cejas P, Belda-Iniesta C, et al. (2004) PI3K/Aktsignalling pathway and cancer. Cancer Treat Rev 30: 193-204.

54. Peterson EA, Andrews PS, Be X, Boezio AA, Bush TL, et al. (2011) Discovery of triazine-benzimidazoles as selective inhibitors of mTOR. Bioorg Med Chem Lett 21: 2064-2070.

55. Zask A, Verheijen JC, Richard DJ, Kaplan J, Curran K et al. (2010) Discovery of 2-ureidophenyltriazines bearing bridged morpholines as potent and selective ATP-competitive mTOR inhibitors. Bioorg Med ChemLett 20: 2644-2647.

56. Poulsen A, Williams M, Nagaraj HM, William AD, Wang $H$, et al. (2012) Structure-based optimization of morpholino-triazines as PI3K and mTOR inhibitors.Bioorg Med Chem Lett 22: 1009-1013.

57. Richard DJ,Verheijen JC, Yu K, Zask A (2010) Triazines incorporating (R)-3methylmorpholine are potent inhibitors of the mammalian target of rapamycin (mTOR) with selectivity over PI3Kalpha. Bioorg Med Chem Lett 20: 2654-2657.

58. Huang Q, Fu Q, Liu YJ, Bai J, Wang Q et al. (2014). Design, Synthesis and Anticancer Activity of Novel 6-(Aminophenyl)-2,4-Bismorpholino-1,3,5-Triazine Derivatives Bearing Arylmethylene Hydrazine Moiety. Chem Res ChinUniv 30: 257-265.

59. Zhu W, Liu Y, Zhao Y, Wang H, Tan L, et al. (2012) Synthesis and biological evaluation of novel 6-hydrazinyl-2,4-bismorpholino pyrimidine and ,3,5-triazine derivatives as potential antitumor agents.Arch Pharm (Weinheim) 345: 812821

60. Dehnhardt CM,Venkatesan AM, Chen Z, Delos-Santos E, Ayral-Kaloustian S et al. (2011) Identification of 2-oxatriazines as highly potent pan-PI3K/mTOR dual inhibitors. Bioorg Med Chem Lett 21: 4773-4778.

61. Wurz RP, Liu L, Yang K, Nishimura N, Bo Y, et al. (2012) Synthesis and structure-activity relationships of dual $\mathrm{PI} 3 \mathrm{~K} / \mathrm{mTOR}$ inhibitors based on a 4-amino-6-methyl-,3,5-triazine sulfonamide scaffold. Bioorg Med ChemLett22: 5714-5720.

62. Shawver LK, Lipson KE, Fong TAT, McMahon G, lowman GD, et al. (1997) Receptor tyrosine kinases as targets for inhibition of angiogenesis. Drug Discov Today 2: 50-63.

63. Ferrara N, Gerber HP, LeCouter J (2003) The biology of VEGF and its receptors. Nat Med 9: 669-676.

64. Prien 01 (2006) The gatekeeper: friend or foe in identifying the next generation of kinase inhibitors. Chem Med Chem 1: 1195-1196.

65. Saijo N (2010) Targeted therapies: Tyrosine-kinase inhibitors--new standard for NSCLC therapy. Nat Rev Clin Oncol 7: 618-619.

66. Engelman JA, JÃanne PA (2008) Mechanisms of acquired resistance to epidermal growth factor receptor tyrosine kinase inhibitors in non-small cell lung cancer.Clin Cancer Res 14: 2895-2899.

67. Katayama T, Shimizu J, Suda K, Onozato R, Fukui T, et al. (2009) Efficacy of erlotinib for brain and leptomeningeal metastases in patients with lung adenocarcinoma who showed initial good response to gefitinib.J ThoracOnco 4: $1415-1419$

68. Vikis H, Sato M, James M, Wang D, Wang $Y$, et al. (2005) EGFR-T790M is rare lung cancer susceptibility allele with enhanced kinase activity. Cancer Res 67: 4665-4670.

69. Bai F, Liu H, Tong L, Zhou W, Liu L, et al. (2012) Discovery of novel selective inhibitors for EGFR-T790M/L858R. Bioorg Med Chem Lett 22: 1365-1370.

70. Yu Q1 (2005) The dynamic roles of angiopoietins in tumor angiogenesis. Future Oncol 1: 475-484

71. Visconti RP, Richardson CD, Sato TN (2002) Orchestration of angiogenesis and arteriovenous contribution by angiopoietins and vascular endothelia growth factor (VEGF).ProcNatlAcadSci U S A 99: 8219-8224.

72. Hodous BL, Geunsa MSD, HughesPE, Albrecht BK, Bellon S, et al. (2007)J. Med. Chem. Lett. 17: 2886-2889.

73. Bump NJ, Arnold LD, Dixon RW, Ho HW, Allen K (2001)Bellamacina, C Method of identifying inhibitors of receptor tyrosine kinase Tie-2 for regulation of neovascularization. WO 01072778, 2001.

74. Kasparec J, Johnson NW, Yuan C, Murray JH, Adams JL (2005) Abstracts of Papers, 229th National Meeting of the American Chemical Society, American Chemical. Society. 229,134.

75. Shen TL, Park AY, Alcaraz A, Peng X, Jang I, et al. (2005) Conditional knockout of focal adhesion kinase in endothelial cells reveals its role in angiogenesis and vascular development in late embryogenesis.J Cell Biol 169: 941-952.

76. Gabarra-Niecko V, Schaller MD, Dunty JM (2003) FAK regulates biologica processes important for the pathogenesis of cancer.Cancer Metastasis Rev 22: $359-374$

77. Dao P, Smith N, Tomkiewicz-Raulet C, Yen-Pon E, Camacho-Artacho M, et al (2015) Design, synthesis, and evaluation of novel imidazo[,2-a][,3,5]triazines and their derivatives as focal adhesion kinase inhibitors with antitumor activity.J Med Chem 58: 237-251.

78. Dao P,Jarray R, Le Coq J, Lietha D, Loukaci A, et al. (2013) Synthesis of nove diarylamino-,3,5-triazine derivatives as FAK inhibitors with anti-angiogenic activity.Bioorg Med Chem Lett 23: 4552-4556.

79. Morgan DO1 (1997) Cyclin-dependent kinases: engines, clocks, and microprocessors.Annu Rev Cell DevBiol 13: 261-291.

80. Hunter T, Pines J (1994) Cyclins and cancer. II: Cyclin D and CDK inhibitors come of age.Cell 79: 573-582.

81. Sielecki TM,Boylan JF, Benfield PA, Trainor GL (2000) Cyclin-dependent kinase inhibitors: useful targets in cell cycle regulation. J Med Chem 43: 1-18.

82. Nikolic M, Tsai LH (2000) Activity and regulation of p35/Cdk5 kinase complex. Methods Enzymol 325: 200-213.

83. Maccioni RB,Otth C, Concha II, MuÃ $\pm 0 z$ JP (2001) The protein kinase Cdk5 Structural aspects, roles in neurogenesis and involvement in Alzheimer's pathology.Eur J Biochem 268: 1518-1527. 
84. Napolitano G,Majello B, Lania L (2002) Role of cyclinT/Cdk9 complex in basal and regulated transcription (review).Int $\mathrm{J}$ Oncol 21: 171-177.

85. Senderowicz AM (2003) Modulators of Cyclin-Dependent Kinases. Cell Cycle Inhib Cancer Ther 179-205.

86. Wang S, Meades C, Wood G, Osnowski A, Anderson S, et al. (2004) Synthesis and biological activity of 2-anilino-4-(1H-pyrrol-3-yl) pyrimidine CDK inhibitors. Bioorg Med Chem Lett14: 4237-4240.

87. Nugiel DA,Vidwans A, Etzkorn AM, Rossi KA, Benfield PA, et al. (2002) Synthesis and evaluation of indenopyrazoles as cyclin-dependent kinase inhibitors. 2. Probing the indeno ring substituent pattern. J Med Chem 45: 5224-5232.

88. Yue EW, Higley CA, DiMeo SV, Carini DJ, Nugiel DA, et al. (2002) Synthesis and evaluation of indenopyrazoles as cyclin-dependent kinase inhibitors. 3 . Structure activity relationships at C3. J Med Chem 45: 5233-5248.

89. Zhu G, Conner SE, Zhou X, Shih C, Li T, et al. (2003) Synthesis, structureactivity relationship, and biological studies of indolocarbazoles as potent cyclin D1-CDK4 inhibitors. J Med Chem 46: 2027-2030.

90. Markwalder JA, Arnone MR, Benfield PA, Boisclair M, Burton CR, et al. (2004) Synthesis and biological evaluation of 1-aryl-4,5-dihydro-1 H-pyrazolo[3,4-d] pyrimidin-4-one Inhibitors of cyclin-dependent kinases. J MedChem 47: $5894-$ 5911.

91. Schoepfer J,Fretz H, Chaudhuri B, Muller L, Seeber E, et al. (2002) Structurebased design and synthesis of 2-benzylidene-benzofuran-3-ones as flavopiridol mimics. J Med Chem 45: 1741-1747.

92. Bos JL1 (1989) ras oncogenes in human cancer: a review.Cancer Res 49: 4682-4689.

93. Noma K, Oyama N, Liao JK (2006) Physiological role of ROCKs in the cardiovascular system. Am J Physiol Cell Physiol 290: C661-668.

94. Nakagawa O, Fujisawa K, Ishizaki T, Saito Y, Nakao K, et al. (1996) ROCKand ROCK-II, two isoforms of Rho-associated coiled-coil forming protein serine/threonine kinase in mice. FEBS Lett 392: 189-193.

95. Mueller BK, Mack H, Teusch N (2005) Rho kinase, a promising drug target for neurological disorders. Nat Rev Drug Discov 4: 387-398.

96. LÃThn M,Plettenburg O, Ivashchenko Y, Kannt A, Hofmeister A, et al. (2009) Pharmacological characterization of SAR407899, a novel rho-kinase inhibitor. Hypertension 54: 676-683.

97. Williams RD,Novack GD, van Haarlem T, Kopczynski C; AR-12286 Phase 2A Study Group (2011) Ocular hypotensive effect of the Rho kinase inhibitor AR12286 in patients with glaucoma and ocular hypertension. Am J Ophthalmol 152: 834-841.

98. Chen J, Runyan SA, Robinson MR (2011) Novel ocular antihypertensive compounds in clinical trials. Clin Ophthalmol 5: 667-677.

99. Mc Kerracher L, Higuchi $\mathrm{H}$ (2006) Targeting Rho to stimulate repair after spinal cord injury.J Neurotrauma 23: 309-317.

100. Shen M, Zhou S, Li Y, Pan P, Zhang L, et al. (2013) Discovery and optimization of triazine derivatives as ROCK1 inhibitors: molecular docking, molecular dynamics simulations and free energy calculations.MolBiosyst 9: 361-374.

101. Maruta $\mathrm{H} 1$ (2014) Herbal therapeutics that block the oncogenic kinase PAK1: a practical approach towards PAK1-dependent diseases and longevity. Phytother Res 28: 656-672.

102. Abo A,Qu J, Cammarano MS, Dan C, Fritsch A, et al. (1998) PAK4, a novel effector for $\mathrm{Cdc} 42 \mathrm{Hs}$, is implicated in the reorganization of the actin cytoskeleton and in the formation of filopodia. EMBO J 17: 6527-6540.

103. Qu J,Cammarano MS, Shi Q, Ha KC, de Lanerolle P, et al. (2001) Activated PAK4 regulates cell adhesion and anchorage-independent growth. Mol Cell Biol 21: 3523-3533.

104.Qu J, Li X, Novitch BG, Zheng Y, Kohn M, et al. (2003) PAK4 kinase is essential for embryonic viability and for proper neuronal development. Mol Cell Biol 23: 7122-7133.

105. Ryu BJ, Kim S2, Min B3, Kim KY2, Lee JS4, et al. (2014) Discovery and the structural basis of a novel p21-activated kinase 4 inhibitor. Cancer Lett 349: 45-50.

106. Neckers L, Ivy SP (2003) Heat shock protein 90.CurrOpinOncol 15: 419-424.

107. Workman P1 (2003) Overview: translating Hsp90 biology into Hsp90 drugs. Curr Cancer Drug Targets 3: 297-300.
108. Milicevic Z,Bogojevic D, Mihailovic M, Petrovic M, Krivokapic Z (2008) Molecular characterization of hsp90 isoforms in colorectal cancer cells and its association with tumour progression. Int J Oncol 32: 1169-1178.

109. Lee T,Seo YH (2013) Targeting the hydrophobic region of Hsp90's ATP binding pocket with novel ,3,5-triazines.Bioorg Med Chem Lett 23: 6427-6431.

110. Suda A, Kawasaki K, Komiyama S,Isshiki Y, Yoon D, et al. (2012) Design and synthesis of novel macrocyclic 2-amino-6-arylpyrimidine Hsp90 inhibitors. Bioorg Med Chem Lett22: 1136-1141.

111. Supuran CT, Scozzafava A, Casini A (2003) Carbonic anhydrase inhibitors Med Res Rev 23: 146-189.

112. Supuran CT1 (2012) Structure-based drug discovery of carbonic anhydrase inhibitors. J Enzyme Inhib Med Chem 27: 759-772.

113. Alterio V, Di Fiore A,Ambrosio KD,Supuran CT, De Simone G (2012) Multiple binding modes of inhibitors to carbonic anhydrases: how to design specific drugs targeting 15 different isoforms. Chem Rev112: 4421-4468.

114. Supuran CT (2013) Carbonic anhydrase inhibitors: an editorial. Expert OpinTher Pat 23: 677-679.

115. Alafeefy AM, Isik S, Abdel-Aziz HA, Ashour AE,Vullo D, et al. (2013) Carbonic anhydrase inhibitors: Benzenesulfonamides incorporating cyanoacrylamide moieties are low nanomolar/subnanomolar inhibitors of the tumor-associated isoforms IX and XII. Bioorg Med Chem 21: 1396-1403.

116. Saluja AK,Tiwari M2, Vullo D3, Supuran CT4 (2014) Substituted benzene sulfonamides incorporating ,3,5-triazinyl moieties potently inhibit human carbonic anhydrases II, IX and XII.Bioorg Med ChemLett 24: 1310-1314.

117. Jain AK, Veerasamy R,Vaidya A, Mourya V, Agrawal RK (2010) QSAR analysis of some novel sulfonamides incorporating 1,3,5-triazine derivatives as carbonic anhydrase inhibitors. Med Chem Res 19: 1191-1202.

118. Pastorekova S, Pastorek J (2004) Cancer-related carbonic anhydrase isozymes and their inhibition. CRC: Boca. Raton. FL. USA. pp-255-281.

119. Pastorekova S,Parkkila S, Pastorek J, Supuran CT (2004) Carbonic anhydrases: current state of the art, therapeutic applications and future prospects.J Enzyme Inhib Med Chem 19: 199-229.

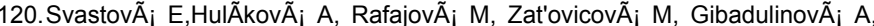
et al. (2004) Hypoxia activates the capacity of tumor-associated carbonic anhydrase IX to acidify extracellular pH. FEBS Lett 577: 439-445.

121.Dubois L, Douma K, Supuran CT, Chiu RK, Scozzafava A, et al. (2007) Imaging the hypoxia surrogate marker CA IX requires expression and catalytic activity for binding fluorescent sulfonamide inhibitors. Radiother Oncol 83: 367-373.

122. Dubois L,Lieuwes NG, Maresca A, Thiry A, Supuran CT, et al. (2009) Imaging of CA IX with fluorescent labelled sulfonamides distinguishes hypoxic and (re)oxygenated cells in a xenografttumour model. RadiotherOncol 92: 423-428.

123. KyllÃđnen MS,Parkkila S, Rajaniemi H, Waheed A, Grubb JH, et al. (2003) Localization of carbonic anhydrase XII to the basolateral membrane of $\mathrm{H+}$ secreting cells of mouse and rat kidney.J HistochemCytochem 51: 1217-1224.

124. Garaj V, Puccetti L, FasolisGi, Winum JY, Montero JL, et al. (2005)Carbonic anhydrase inhibitors: Novel sulfonamides incorporating 1,3,5-triazine moieties as inhibitors of the cytosolic and tumour-associated carbonic anhydrase isozymes I, II and IX. Bioorg Med Chem Lett15: 3102-3108.

125. Garaj V, Puccetti L,Fasolis G, Winum JY, Montero JL, et al. (2004) Carbonic anhydrase inhibitors: synthesis and inhibition of cytosolic/tumor-associated carbonic anhydrase isozymes I, II, and IX with sulfonamides incorporating 1,2,4-triazine moieties. Bioorg Med Chem Lett 14: 5427-5433.

126. Carta F,Garaj V, Maresca A, Wagner J, Avvaru BS, et al. (2011) Sulfonamides incorporating 1,3,5-triazine moieties selectively and potently inhibit carbonic anhydrase transmembrane isoforms IX, XII and XIV over cytosolic isoforms I and II: solution and X-ray crystallographic studies. Bioorg Med ChemLett 19 : 3105-3119.

127. Warburg O, Wind F, Negelein E (1927) THE METABOLISM OF TUMORS IN THE BODY.J Gen Physiol 8: 519-530.

128. Pelicano H, Martin DS, Xu RH, Huang P (2006) Glycolysis inhibition for anticancer treatment.Oncogene 25: 4633-4646.

129. Xu RH,Pelicano H, Zhou Y, Carew JS, Feng L, et al. (2005) Inhibition of glycolysis in cancer cells: a novel strategy to overcome drug resistance associated with mitochondrial respiratory defect and hypoxia.Cancer Res 65 613-621. 
Citation: Liu B, Sun T, Zhou Z, Du L (2015) A Systematic Review on Antitumor Agents with 1, 3, 5-triazines. Med chem 5: 131-148. doi:10.4172/21610444.1000255

130.Shi T, Yu A, Li M, Zhang M, Xing L,et al. (2013) Identification and characterization of a novel C20-elongase gene from the marine microalgae, Pavlovaviridis, and its use for the reconstitution of two pathways of longchain polyunsatured fatty acids biosynthesis in Saccharomyces cerevisiae. BiotechnolLett 35: 1271-1282.

131. Jordan A, Hadfield JA, Lawrence NJ, McGown AT (1998) Tubulin as a target for anticancer drugs: agents which interact with the mitotic spindle.Med Res Rev 18: 259-296.

132. Nguyen TL, McGrath C, Hermone AR, Burnett JC, Zaharevitz DW, et al (2005) A common pharmacophore for a diverse set of colchicine site inhibitors using a structure-based approach.J Med Chem 48: 6107-6116.

133. Lippert JW 3rd1 (2007) Vascular disrupting agents.Bioorg Med Chem 15: 605615.

134. Cragg GM, Newman DJ (2004) A tale of two tumor targets: topoisomerase and tubulin. The Wall and Wani contribution to cancer chemotherapy.J Nat Prod 67: 232-244

135. Nicolaou KC, Dai WM, Guy RK (1994) Chemistry and biology of taxol. AngewChemlnt Ed 33: 15-44.

136. Kim YJ,Sackett DL, Schapira M, Walsh DP, Min J, et al. (2006) Identification of 12 Cysbeta on tubulin as the binding site of tubulyzine.Bioorg Med Chem 14: 1169-1175.

137. Nam NH1 (2003) Combretastatin A-4 analogues as antimitotic antitumor agents.Curr Med Chem 10: 1697-1722.

138. Reider PJ, Roland DM, Maytansinoids (1984) In The Alkaloids; Brossi, A., Ed.; Academic. Press. p 23.

139. Abal M,Andreu JM, Barasoain I (2003) Taxanes: microtubule and centrosome targets, and cell cycle dependent mechanisms of action.Curr Cancer Drug Targets 3: 193-203.

140. Moon HS, Jacobson EM, Khersonsky SM, Luzung MR, Walsh DP, et al. (2002) A novel microtubule destabilizing entity from orthogonal synthesis of triazine library and zebrafish embryo screening. J Am ChemSoc 124: 11608-11609.

141.Popowycz F, Schneider C, Debonis S, Skoufias DA, Kozielski F, et al. (2009) Synthesis and antiproliferative evaluation of pyrazolo[,5-a]-,3,5-triazine myoseverin derivatives.Bioorg Med Chem 17: 3471-3478.
142. Malysheva YB,Combes S, Allegro D, Peyrot V, Knochel P, et al. (2012) Synthesis and biological evaluation of novel anticancer bivalent colchicinetubulizine hybrids.Bioorg Med Chem 20: 4271-4278.

143. Kisselev AF, van der Linden WA, Overkleeft HS (2012) Proteasome inhibitors: an expanding army attacking a unique target.ChemBiol 19: 99-115.

144. Shekhar MPV, Lyakhovich A, Visscher DW, Heng H, Kondrat N (2002) Rad6 overexpression induces multinucleation, centrosome amplification, abnormal mitosis, aneuploidy, and transformation. Cancer Res 62: 2115-2124.

145. Shekhar MP, Gerard B, Pauley RJ, Williams BO, Tait L (2008) Rad6B is a positive regulator of beta-catenin stabilization.Cancer Res 68: 1741-1750.

146. Sanders MA,Brahemi G,NangiaâMakker P,Balan V,Morelli M, et al. (2013) Novel Inhibitors of Rad6 Ubiquitin Conjugating Enzyme: Design, Synthesis, Identification, and Functional Characterization. Mol Cancer Ther12: 373-383.

147. Kothayer H,Elshanawani AA, Abu Kull ME, El-Sabbagh OI, Shekhar MP, et al. (2013) Design, synthesis and in vitro anticancer evaluation of 4,6-diamino,3,5-triazine-2-carbohydrazides and -carboxamides.Bioorg Med ChemLett 23: 6886-6889.

148.Zhao X, Tan Q, Zhang Z, Zhao Y (2014) 1,3,5-Triazine inhibitors of histone deacetylases: synthesis and biological activity. MedChemRes 23: 5188-5196.

49. Feyen F,Cachoux F, Gertsch J, Wartmann M, Altmann KH (2008) Epothilones as lead structures for the synthesis-based discovery of new chemotypes for microtubule stabilization.AccChem Res 41: 21-31.

150. Foster BJ, Harding BJ, Leyland-Jones B, Hoth D (1986) Hexamethylmelamine a critical review of an active drug.Cancer Treat Rev 13: 197-217.

151. Ono M, Kawahara N, Goto D, Wakabayashi Y, Ushiro S, et al. (1996) Inhibition of tumor growth and neovascularization by an anti-gastric ulcer agent, irsogladine.Cancer Res 56: 1512-1516.

152. Nozaki S, Maeda M, Tsuda H, Sledge GW Jr (2004) Inhibition of breast cance regrowth and pulmonary metastasis in nude mice by anti-gastric ulcer agent irsogladine. Breast Cancer Res Treat 83: 195-199.

153. Kumar R, Gupta L, Pal P, Khan S, Singh N, et al. (2010) Synthesis and cytotoxicity evaluation of (tetrahydro-beta-carboline)-,3,5-triazine hybrids as anticancer agents. Eur J Med Chem 45: 2265-2276. 